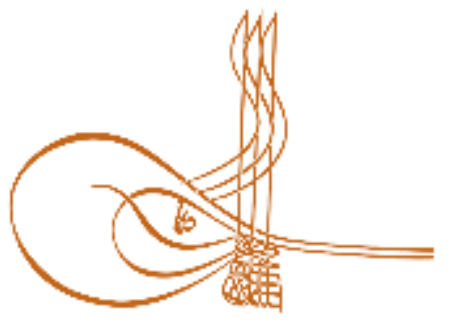

www.turkishstudies.net/turkishstudies
Turkish Studies

eISSN: $1308-2140$

Research Article / Araştırma Makalesi

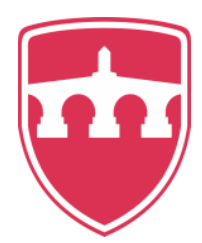

INTERNATIONAL

BALKAN

UNIVERSITY

Sponsored by IBU

\title{
Enneagram Türkiye Kişilik Envanteri’nin Geliştirilmesi ve Psikometrik Özelliklerinin Belirlenmesi
}

\author{
Enneagram Personality Inventory Development and Determination of Turkey Psychometric \\ Properties
}

Turgay Şirin*

\begin{abstract}
The purpose of this study is to develop the original Enneagram Turkey Personality Inventory and the validity and reliability studies in Turkey sample. The inventory was applied to 1110 people in 723 women $(65.13 \%)$ and 387 men (34.86\%) aged between 17-62 (23.23 \pm 6.51$)$ in 3 stages. Enneagram Turkey Inventory, for each subscale index profile is an inventory such as MMPI is subjected to principal components analysis in accordance with its varimax rotation. As a result of the factor analysis, the final form of the inventory with 54 questions in 9 sub-factors was developed. In the development process of the scale, Lawshe analysis, exploratory factor analysis, reliability analysis, test-retest and convergent validity studies, and confirmatory factor analysis (CFA) studies were conducted and reported. In reliability analysis, Cronbach alpha value for total scale was found to be between 0.89 and $0.60-0.78$ for subscales; Item-total correlations were found above 0.30 for each subscale. Correlation coefficients in test-retest analysis are between $0.20-0.57$. In addition, in the confirmatory factor analysis (DFA) conducted as a result of the last study of the scale, the fit indices of the model tested were found to be appropriate $[(\chi 2(2545,804, \mathrm{sd}=1027, \mathrm{p}=.000) ; \chi 2 / \mathrm{sd}=2.47$; RMSEA $=0.06$; $\mathrm{SRM}=0.07 ; \mathrm{GFI}=0.97 ; \mathrm{AGFI}=0.94 ; \mathrm{CFI}=0.92 ; \mathrm{IFI}=0.92 ; \mathrm{NFI}=0.91 ; \mathrm{RFI}=0.87]$. the applications result in accordance with the obtained validity and reliability analysis findings Enneagram Turkey Personality inventory (ETPI) is understood to be a valid and reliable scale.
\end{abstract}

\section{Structured Abstract: Introduction}

Enneagram, done a lot of work on in the world, is a personality typology system also increasing awareness gradually Turkey. It is a personality theory that basically diverges from each other but has a dynamic relationship between the types and consists of nine different thinking, feeling and acting patterns (Daniels and Price, 2004, p. 13).

Enneagram word Greek "nine", meaning " ennea " and "spots" in the sense of "Grammos " has emerged with a combination of words. The "Enneagram Scheme" symbolized by a nine-pointed star shows the development of an event from its initial moment at all stages in the world (Palmer, 2014: 25). Gurdjieff says that the Enneagram is built on three centers: thought, emotion and movement (Ouspensky, 2010, p. 101).

\footnotetext{
${ }^{*}$ Doç. Dr., İstanbul Sabahattin Zaim Üniversitesi, İslami İlimler Fakültesi, İslami İlimler Bölümü Assoc. Prof. Dr., Istanbul Sabahattin Zaim University, Faculty of Islamic Education, Department of Islamic Sciences ORCID 0000-0002-4872-7386

turgay.sirin@izu.edu.tr veya turgaysirin@gmail.com

Cite as/ Atıf: Şirin T. (2020). Enneagram Türkiye Kişilik Envanteri'nin geliştirilmesi ve psikometrik özelliklerinin belirlenmesi, Turkish Studies, 15(2), 1375-1398. https://dx.doi.org/10.29228/TurkishStudies.42149

Received/Geliş: 15 March/Mart 2020

Accepted/Kabul: 25 April/Nisan 2020

Copyright $\mathbb{C}$ MDE, Turkey
} 
Today's Enneagram has no clear written history. It takes its source from the ancient esoteric teachings, especially the Islamic Sufi teachings. The enneagram was known in the West by George Ivanovich Gurdjieff (1866-1949). Gurdjieff 's acquaintance with the enneagram occurred during his travels at the end of the 19th century at the beginning of the 20th century (Perry and Lefort, 2011, p.713; Christlieb, 2016, p.30-31).

Gurdjief grew up in Kars city of Turkey. Gurdjief traveled within the Islamic geography and met with the sheikhs who followed the Islamic Sufi teaching. These sheikhs are briefly Hakımm Abdülkadir (Carpet Merchant, Adana), Hasim Muhammed (Calligrapher, Baghdad), Sheikh Davud Yusuf (Karbala, Iraq), Atâullah Kirmanî (Bakırcı, Damascus), Sheikh Hasan Efendi (Jerusalem), Sheikh, Pîr Dâvûd (Istanbul ), Şeyh Şah Nâz (Konya) et al. We can count it as (Perry and Lefort, 2011).

Today, enneagram has been widely used in many places in the business world, academic studies, etc. ( Palmer, 1995; Hebenstreit, 2016; Lapid-Bodga, 2004; Lapid-Bodga, 2009; Chestnut, 2017). Tests in accordance with the Enneagram Personality theory are common in Western countries (Wagner and Walker, 1983). However, it is understood that the test in Turkey about enneagram very little (e.g., Yilmaz et al. 2014).

Therefore, according to Turkey, can provide reasonable number of questions and usability features, the need for the development of a publicly available Enneagram Personality Inventory. Therefore the aim of this study is to develop the appropriate implementation of an enneagram personality inventory and validity and reliability studies for Turkey.

\section{Method}

The study was carried out in 3 stages. In the first study, 113 questionnaires, which were not subjected to factor analysis of the scale, were applied to a total of 623 people between the ages of 17-62 (24.64 \pm 7.6$)$, 340 were female $(54.6 \%)$ and 283 were male (45.4\%). After the first study, test-retest and convergent validity for a total of 95 students, $73(76.8 \%)$ and 22 men (23.2\%), 18-31 (20.37 \pm 1.95$)$ work has been done. Enneagram Turkey Inventory, for each subscale index profile is an inventory such as MMP is subjected to principal components analysis in accordance with its varimax rotation. In this context, a final sample of 54 questions with 310 girls (79.1\%) and 82 boys (20.9\%) was applied to a different sample of 392, confirmatory factor analysis was performed. Thus, 723 women $(65.13 \%)$ and 387 men (34.86\%) with a total of 17-62 (23.23 $\pm 6.51)$ were applied to 1110 people in total.

\section{Result and Discussion}

Turkey Enneagram Personality Inventory in the development process, the validity and reliability of scales made and reported. Within the scope of the validity of the scale, lawshe analysis was made and as a result of the analysis, KGO value was determined as 0.79 and KGI as 0.87 . Accordingly, it is understood that the inventory items we obtained as a result of expert opinions provide scope validity, since the minimum value of the CGO at $\alpha=0.05$ significance level is stated as 0.75 for 8 experts (Ayre and Scally, 2014). The fact that the obtained CGI value is greater than the CIS value (CGI> CGI) indicates that the scope validity of the items remaining on the scale is statistically significant (Lawshe 1975).Factor analysis was performed to determine the construct validity of the scale. For this operation, factors with Eiegen values above 1 and explaining the majority of the total variance were selected. Each factor was analyzed in itself (KMO $=0.819$; Aprprox. Chi Square 6806,$653 ; \mathrm{df}=1128 ; \mathrm{p}=0.00)$. As a result of this process, inventory was developed as a 54 -item inventory with 9 sub-factors, according to the personality theory.

In the reliability analysis, it was determined that the Cronbach alpha value for the total scale was between 0.89 and $0.60-0.78$ for the sub-scales; Item-total correlations were found above 0.30 for each subscale. Correlation coefficients in test-retest analysis are between $0.20-0.57$. In addition, in the confirmatory factor analysis (DFA) conducted as a result of the last study of the scale, the fit indices of the model tested were found to be appropriate $[(\chi 2(2545,804, \mathrm{sd}=1027, \mathrm{p}=.000) ; \chi 2 / \mathrm{sd}=2.47 ; \mathrm{RMSEA}=0.06 ; \mathrm{SRMR}=0.07 ; \mathrm{GFI}=$ 0.97; $\mathrm{AGFI}=0.94 ; \mathrm{CFI}=0.92 ; \mathrm{IFI}=0.92 ; \mathrm{NFI}=0.91 ; \mathrm{RFI}=0.87]$

According to the results validity and reliability studies, Enneagram Turkey Personality Inventory has been found to be a valid and reliable inventory. 
Factor analysis was performed to determine the construct validity of the scale. For this operation, factors with Eiegen values above 1 and explaining the majority of the total variance were selected. Each factor was analyzed in itself $(\mathrm{KMO}=0.819$; Aprprox. Chi Square 6806,653; $\mathrm{df}=1128 ; \mathrm{p}=0.00)$. As a result of this process, inventory was developed as a 54-item inventory with 9 sub-factors, according to the personality theory.

In the reliability analysis, it was determined that the Cronbach alpha value for the total scale was between 0.89 and $0.60-0.78$ for the sub-scales; Item-total correlations were found above 0.30 for each subscale. Correlation coefficients in test-retest analysis are between 0.20-0.57. In addition, in the confirmatory factor analysis (DFA) conducted as a result of the last study of the scale, the fit indices of the model tested were found to be appropriate $[(\chi 2(2545,804, \mathrm{sd}=1027, \mathrm{p}=.000) ; \chi 2 / \mathrm{sd}=2.47$; RMSEA $=0.06$; $\mathrm{SRMR}=0.07$; GFI $=$ 0.97; AGFI $=0.94 ; \mathrm{CFI}=0.92 ; \mathrm{IFI}=0.92 ; \mathrm{NFI}=0.91 ; \mathrm{RFI}=0.87]$ According to the results validity and reliability studies, Enneagram Turkey Personality Inventory has been found to be a valid and reliable inventory.

Keywords: Psychology, Enneagram, Personality, Scale Development, Validity and Reliability

Öz: Bu çalışmanın amacı, Enneagram kişilik teorisi kapsamında, Türkiye örnekleminde özgün bir Enneagram Kişilik Envanteri'nin geliştirilmesi ve geçerlilik-güvenilirlik çalışmalarının yapılmasıdır. Envanter 3 aşamada,

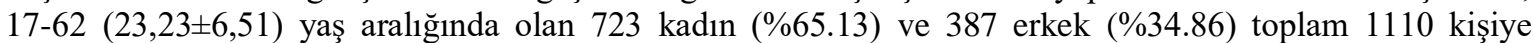
uygulanmıştır. Enneagram Türkiye Envanteri, MMPI gibi profil indeksli bir envanter olduğu için her alt ölçek, kendi içinde Varimax döndürmesine göre temel bileşenler analizine tabi tutulmuştur. Yapılan faktör analizi sonucunda envanterin 9 alt faktörde 54 soruluk nihai formu geliştirilmiştir. Ölçeğin geliştirme sürecinde Lawshe analizi, açımlayıcı faktör analizi, güvenirlik analizleri, test tekrar test ve yakınsak geçerlik çalışmaları ile doğrulayıcı faktör analizi (DFA) çalışmaları yapılmış ve raporlanmıştır. Güvenilirlik analizinde, toplam ölçek için Cronbach alfa değerinin 0.89 ve alt ölçekler için $0.60-0.78$ arasında olduğu saptanmış; her alt ölçek için madde-toplam korelasyonları 0.30 'un üzerinde bulunmuştur. Test-tekrar test analizinde korelasyon katsayıları 0.20-0.57 arasındadır. Ayrıca ölçeğin son çalışması sonucunda yapılan doğrulayıcı faktör analizinde (DFA) test edilen modelin uyum endekslerinin uygun olduğu saptanmıştır [ $\chi 2(2545,804, \mathrm{sd}=1027, \mathrm{p}=.000)$; $\chi 2 / \mathrm{sd}=2,47 ; \mathrm{RMSEA}=0.06 ; \mathrm{SRMR}=0.07 ; \mathrm{GFI}=0.97 ; \quad \mathrm{AGFI}=0.94 ; \mathrm{CFI}=0.92 ; \mathrm{IFI}=0,92 ; \mathrm{NFI}=0.91$; $\mathrm{RFI}=0.87$ ]. Sonuç olarak geçerlilik ve güvenilirlik analizi bulgularına göre Enneagram Türkiye Kişilik Envanteri'nin (ETKE) geçerli ve güvenilir bir envanter olduğu söylenebilir.

Anahtar Kelimeler: Psikoloji, Enneagram, Kişilik, Ölçek Geliştirme, Geçerlik ve Güvenirlik

\section{Giriş}

Enneagram, dünyada üzerine oldukça fazla çalışma yapılan, Türkiye'de de gittikçe bilinirliği artan bir kişilik tipolojisi sistemidir. Temel olarak birbirinden ayrışan ama bir o kadar da tipler arasında dinamik bir ilişkinin olduğu, dokuz farklı düşünme, hissetme ve eyleme geçme kalıbından oluşan bir kişilik teorisidir (Daniels ve Price, 2004, s.13).

Enneagram kelimesi yunanca "dokuz" anlamındaki "ennea" ve "noktalar" anlamındaki "grammos" kelimelerinin birleşimi ile ortaya çıkmıştır. Dokuz köşeli yıldız ile sembolize edilen "Enneagram Şeması" bir olayın başlangıç anından dünyadaki tüm aşamalarındaki gelişimini göstermektedir (Palmer, 2014, s. 25). Riso ve Hudson (2009, s. 14-15) enneagramın öncelikli kullanım alanını; kendini tanıma ve dönüşüm olarak ifade ederek, bireyin kişilik tarzını tanıdıkça erken dönemde savunma amaçlı oluş̧urduğu kişiliği farkedebileceğini ifade etmişlerdir. Ayrıca diğer kullanım alanını ise insanları tanıyarak farklı düşünce, duygu ve davranışları anlamlandırıp, nesnel bakış açısının kazanılması olarak açıklamışlardır.

Enneagram, eski geleneklerin modern bir sentezidir. Enneagram kişilik teorisi; hem teolojik ve tinsel hem de psikolojik etkenleri içeren, dünyayı anlamlandırmada, kişilerarası iletişimde, kendini tanımlamada bireyin belirgin düşünce ve tutumlarını ifade eden psikolojik bir yol haritası, bireyin tercihleri, motivasyon kaynakları, düşünce, duygu ve eylemleri hakkındaki bilgileri içeren 
bir kişilik şablonudur (Riso ve Hudson, 2009). Bu şablonu oluşturan unsurlar ise bilinçli farkındalıktan ziyade alışkanlık ve şartlanma ile oluşmaktadır. Enneagram, seçimlerde ve motivasyonda farkındalık oluşturarak, hayata anlam katan, dönüşüm olarak ifade edilen gerçek benliğe ulaşma firsatı tanıyan bir yolculuktur (Giordano, 2008, s. 6). Bu yolculukta kişinin kendini ifade edebilmesi ve insanlarla doğru bir iletişime geçebilmesi için kendisini tanıması gerekmektedir. Birey, kişilik tipinin otomatik tepkilerini farkederek, onlara sahip çıkmak yerine kendi özüne ulaşıp, özgürce potansiyellerini farkedebilir.

Enneagram sisteminde bulunan kişilik tipleri; gerçek benliğin önüne geçen dokuz farklı düşünce, duygu ve davranış kalıplarını tanımlayarak, otomatik tepkileri, tutumları ve savunmaları anlamlandırıp, var olan potansiyelin açığa çıkmasına yardımcı olarak, bireyin psikolojik gelişime imkân sağlamaktadır (Chestnut, 2008, s.28). Naranjo (1994, s. 5-6), kişiliğin erken dönemden itibaren yaşam boyunca deneyimlenen durumlar neticesinde oluştuğunu, yaşanılan benzeri durumlarda ise potansiyelin kullanılmadan, yeniliğe imkân tanınmadan otomatik olarak deneyimlerden yararlandığını ifade etmiştir. Chestnut (2008, s. 49-50) hayata uyum sağlayabilmek için oluşturulan, "sahte benlik" olarak ifade ettiği kişiliğin kökenlerinin ve yapısının incelenerek tanınmasında enneagram sisteminin kullanılabileceğini bildirmiştir. Özellikle kişilik tipolojisindeki sistematik ve uygulanılabilir yapısı ile çağdaş psikolojik teorileri ve manevi öğretileri kendi bünyesinde pragmatik olarak birleştirmesinden dolayı güçlü bir "transpersonal psikoloji" modeli olarak enneagramı tanımlamıştır. Wagner ve Walker (1983, s. 715-716) da enneagramın yüzyıllar boyunca doğu ezoterik okullarda hem kişiliği tanımlamak amaçlı hem de terapötik amaçlı kullanıldığını bildirmişlerdir.

Günümüzde enneagram iş dünyasında, akademik çalışmalarda vb pek çok yerde yaygın bir kullanıma ulaşmıştır (Palmer, 1995; Hebenstreit, 2016; Lapid-Bodga, 2004; Lapid-Bodga, 2009; Chestnut, 2017). Bununla birlikte Enneagram Kişilik teorisine uygun testlerin Batılı ülkelerde geliştirildiği de görülmektedir (Wagner and Walker, 1983). Ancak Türkiye'de bu hususta geliştirilen testlerin çok az olduğu (örneğin Yılmaz ve ark. 2014) anlaşılmaktadır. Bu sebeple Türkiye örnekleminde, makul soru sayısı ve kullanışlılık özelliklerini sağlayabilecek, genel kullanıma açık bir Enneagram Kişilik envanterinin geliştirilmesi ihtiyacı hissedilmiştir. Kısaca bu çalışmanın amacı, Türkiye örnekleminde, Enneagram kişilik teorisi kapsamında özgün bir Enneagram Kişilik Envanteri’nin geliştirilmesi ve geçerlilik-güvenilirlik çalışmalarının yapılmasıdır.

\section{Enneagram Kișilik Sisteminin Tarihi}

Enneagramın kökeni 4600 yıl öncesi Gılgamış destanı döneminde Mezapotamya'da "Bilginin Kardeşliği”" olarak anılan ezoterik birlik tarafından sırrın keşfedilemesine ve nesilden nesile aktarılmasına dayandığını ifade eden kaynaklar bulunmaktadır (Risso ve Hudson; 2009; Daniels ve Price, 2004; Gurdijef, 2009). Milattan önce 524 yllında Babil'de içlerinde Zoroaster, Pisagor gibi bilginlerin bulunduğu bir grub tarafından açıklanan enneagram; öğretiyi koruyan kişilerin göçler vasıtasıyla Buhara'ya gitmeleri, 10. yüzyılda Müslüman bilim adamlarının sıfırı bulmaları ve ondalık say1 sistemi ile entegre etmeleri sonucunda kendini yenileyerek varlığını korumuştur (Bennett, 1974: 27-28; Gurdijef, 2009). Enneagram; Babil kültürünün doğduğu yerlerden Buhara ve Nişabur bölgesine kadar uzanan alanda Keldaniler, Persler, Misırlılar ve Yunanlılar sonrasinda Arap ve Hıristiyanları da içeren bir bilgi alışverişi neticesinde varlığını muhafaza etmiştir. Asıl gelişimini 10. Yüzyıl ve sonrasında İslam Tasavvuf öğretisi içerisinde tamamlayan enneagram'ın Batı'ya taşınması George Ivanovich Gurdjieff tarafından gerçekleşmiştir (Christlieb, 2016, s.30-31; Perry ve Lefort, 2011).

Günümüz Enneagram'1, sufi öğretiler başta olmak üzere kadim ezoterik öğretilerden kaynağını almaktadır ve net bir yazılı tarihi yoktur. Enneagramın Batı'da bilinmesi George Ivanovich Gurdjieff (1866-1949) vasıtasıyla gerçekleşmiştir. Gurdjieff' in enneagramla tanışması 19. yüzyılın sonu 20. yüzyılın başında yaptığı seyahatler sırasında gerçekleşmiştir (Perry ve Lefort, 2011, s.7-13; 
Christlieb, 2016, s. 30-31). Türkiye'nin Kars ilinde büyümüş olan Gurdjief, İslam coğrafyası içerisinde seyahatlerde bulunmuş ve burada İslâm tasavvuf öğretisini takip eden şeyhlerle görüşmüş̧ür. Bu şeyhleri kısaca Hakîm Abdülkadir (Halı Tüccarı, Adana), Hâş̧im Muhammed (Hattat, Bağdat), Şeyh Davud Yusuf (Kerbela, Irak), Atâullah Kirmanî (Bakırcı, Şam), Şeyh Hasan Efendi (Kudüs), Şeyh, Pîr Dâvûd (İstanbul), Şeyh Şah Nâz (Konya) vd. şeklinde sayabiliriz (Perry ve Lefort, 2011).

Gurdjieff 1920 yıllarında Fransa'da "İnsanın Ahenkli Gelişimi Enstitüsünü” (The Institute for the Harmonious Development of Man) kurarak, hareket ve dans egzersizleri ile içsel gözlem ve dikkat çalışmaları üzerinde durmuş, enneagramın matematiksel özellikleri üzerinde çalışmalar yaptırmıştır. Psikolog Peter Demianovich Ouespensky, Gurdjief' in görüşleri ve içsel gelişim üzerine birçok çalışma yapmış, tamponlar olarak ifade edilen savunma mekanizmalarına dikkatleri çekmiştir (Palmer, 2014, s. 26-33). Enneagram'in güncel kişilik tiplerini kategorize eden ve özelliklerini açıklayan çağdaş versiyonunun oluşmasına en büyük katkıyı Bolivya'lı bir psikolog olan Oscar Ichazo yapmıştır. Oscar Ichazo, Buenos Aires'te bulunan okuldan sonra Asya gezisinin ardından öğrendiklerini yaymak için Şili'de 1970 yılında Arica Okulu'nu kurmuş, geleneksel Enneagram felsefesini ve sembolünü modern psikoloji bilgisi ile birleştirerek şimdiki haline getirmiştir. Ünlü psikolog Claudio Naranjo da bu okula gelerek sistemin temelleri ve pratiği üzerine çalışmalar yapmıştır (Riso ve Hudson, 2009, s. 37-39). Naranjo da Enneagramı Batı psikoloji modeli ile sentezleyerek, enetellektüel olarak güçlendirmiştir (Riso ve Hudson, 2009, s. 73-75). Naranjo'nun öğrencisi olan Helen Palmer, enneagram sistemini psikolojik açıdan incelemek yerine sezgi ve manevi alanı ile ilgilenmiş, dikkat ve sezgi üzerine çalışmalar yapmıştır (Palmer, 2014, s. 75-77). Palmer'ın öğrencisi olan David Daniels kişiliğin tespitinden sonra her kişiliğe özgü yapılacak egzersizleri Virginia Price ile derlemiştir (Daniels ve Price, 2016, s. 12). Don Richard Riso ve Russ Hudson ise 1997 yılında Enneagram Enstitüsünü kurarak sistemin gelişimine önemli bir katk1 sağlamıştır (Riso ve Hudson, 2009).

\section{Enneagram Kişilik Sisteminin Yapısı}

Enneagram şekli üzerindeki noktaların her biri temel bir kişilik tipine karşıllk gelmektedir. Kişiliğin bu tiplerden hangisine uyduğu ise karmaşık birtakım testlerden sonra ortaya çıkmaktadır. Normalde insan bu kişilik tiplerinin tüm özelliklerini bir ölçüde kendinde barındırıyorsa da bunlardan biri daha baskın ve belirgindir. Bu nokta, onun asıl kişilik tipini oluşturmaktadır. Fakat kişi çok huzur ve güven içinde yaşıyorsa "güven veya rahat noktası" denilen noktanın kişilik özellikleri göstermeye başlar. Stres ve baskı altında ise "stres noktası" denilen kişilik tipinin özelliklerini sergilemeye başlar. $\mathrm{Bu}$ yönlerin isimleri ve yönlerinin yorumları farklı yorumcular açısından değişiklik göstermektedir (Palmer, 2014; Risso ve Hudson, 2009). Enneagram sembolünde her kişilik tipinin sağında ve solunda bulunan noktalar, ilgili kişilik tipinin "kanat tipleri” olarak adlandırılmaktadır. Palmer (2014, s. 64) kanat etkisi ile her tipin kendi tarzı içinde farklılık gösterebileceğini ifade etmiştir. Kısaca Enneagram şekli üzerindeki nokta, numara ve çizgilerin yerleşimi ve sıralamasının özel anlamı vardir.

Enneagram sistemine göre birey; kendi tarzı, kanat tarzı, gelişme ve çökme yönü ona stres ve rahat olmak üzere dört tarzın etkisinde, bulunduğu merkez ve tarzının seviyeleri ile etkileşim halindedir. Gurdjieff Enneagramın düşünce, duygu ve hareket olmak üzere üç merkez üzerine inşa edildiğini ifade etmektedir (Ouspensky, 2010, s. 101). Enneagram sembolündeki çemberin içinde üçgen oluşturan tip 3, 6 ve 9 bu merkezleri gösteren ana tiplerdir. Her tip, kanat tipleriyle birlikte üç merkez ile ilişkili ancak bir merkezde yoğunlaşmaktadır (Risso ve Hudson, 2009, s. 96-97). Bu merkezlerin her biri de kendi içinde üç farklı kişilik tipolojisi barındırmaktadır. Buna göre Tip 2, Tip3, ve Tip 4 "duygusal (feeling) merkezi"; Tip 5, Tip 6 ve Tip 7 "Zihinsel (thinking) Merkezi" ve Tip 8, Tip 9, Tip1 de "İçü̈düsel (instinctive) Merkezini”" oluşturmaktadır (Risso ve Hudson, 2009; Daniels ve Price, 2004; Palmer, 2014). 
Enneagram sembolündeki iç çizgiler, bireyin günlük hayattaki ruhsal değişimine de açıklık getirebilmektedir. Stres durumunda, kendi tarzı ile baş edemediğinde stres noktasına yönelecek, rahat durumunda ise kendini güvende hissederek gelişim yönünde rahat noktasına hareket edebilecektir (Riso ve Hudson, 2009, s. 33). Rahat yönler okun tersi istikametinde, stres yönler ise okun ucunun gösterdiği istikamettedir (Daniels ve Price, 2016, s. 30). Literatürde ok yönleri ile stres ve rahat noktalarının yorumları ise farklı enneagram yorumcularında değişiklik göstermektedir.

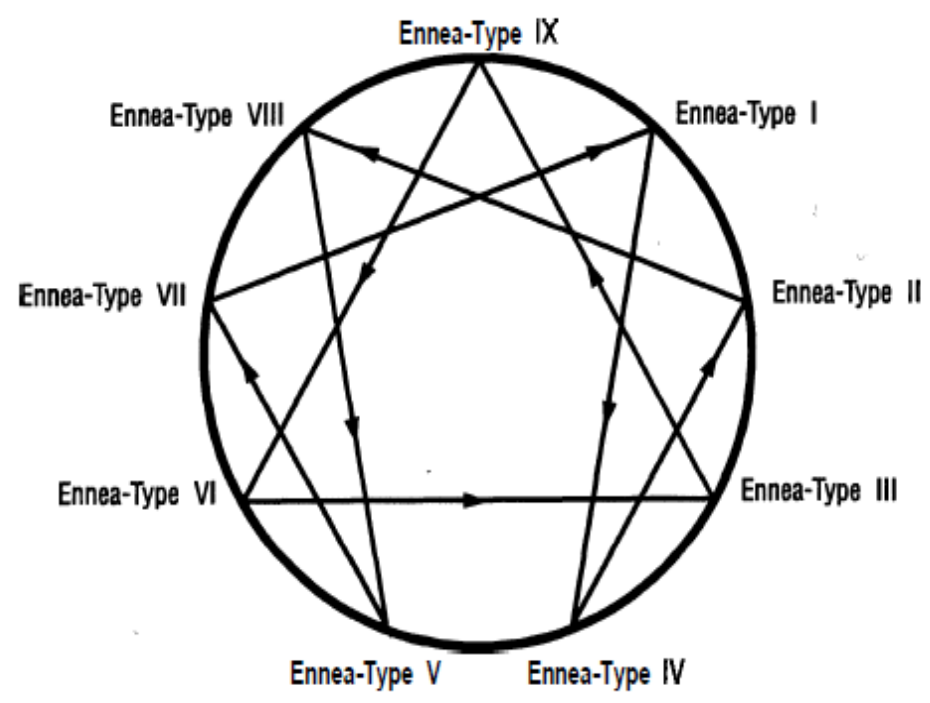

Şekil 1: Enneagram Sembolü ve Kişilik Tiplerinin Rahat ve Stres Yönleri (Naranjo, 1994, s. 14).

\section{Enneagram Kișilik Tipleri}

Enneagram sisteminde Riso ve Hudson'a göre her tarz kendi içinde üç sağlıklı, üç averaj, üç de sağlıksız olmak üzere dokuz seviyede dikey olarak aşağı yukarı hareket edebilirken dokuz farklı kişilik tipi de dinamik bir şekilde çember içinde birbirleriyle bağlantılıdır (Riso ve Hudson, 2009, s. 150-151). Kategorize edilmenin sabitliği ve durağanlığı, enneagram kişilik sisteminde yoktur. Her tarz, genel örüntüsü ile paylaşılırken, bu örüntüler içinde biricik ve özeldir. Her tarz, diğer tarzlardan ayrıldığ 1 gibi tarzlar içindeki bireyler de birbirlerinden ayrılabilirler. Tarzların isimlendirilmesinde tarzın sağlıklı seviyesindeki özellikler kullanılmıştır (Riso ve Hudson, 2009, s. 24-28).

Farklı enneagram yorumcularının (örneğin; Daniels ve Price, 2016; Riso ve Hudson, 2009; Palmer, 2014). ennegram kişilik tariflerinden çıkarılan enneagram kişilik tipleri aşağıdaki şekilde kisaca tarif edilebilir:

Tip 1: Bir numaralı kişilik tipleri düzen arayan, kusursuzluk peşinde, sorumluluk sahibi, disiplinli, kuralcı olup ideal olanı isterler. Beklentilerinden farklı bir durum ile karşılaştıklarında davranışları ile rahatsızlıklarını bildirip, yargılama yolunu seçebilirler. İdeal olanı gösterme uğruna öfkelerini bastırabilirler. Ahlaki değerlere önem verir, yanlışlar üzerine yoğunlaşabilirler. Eşyalar konusunda düzenlidirler.

Tip 2: İki numaralı kişilik tipleri, insanları mutlu etmek, sevilmek ve ihtiyaç duyulmak odaklı bireylerdir. Yardımsever, cömert, empati yeteneği gelişmiş, hassas, fedakâr ancak bekledikleri ilgiyi göremediklerinde ya da istekleri karşılanmadığında talepkâr ve baskıcı olabilirler.

Tip 3: İmaja, dış görünüşe, statüye önem veren, duruma göre politik davranan üçler bireyci ve hırslıdırlar. Çevrelerini manipüle etme, yönlendirme kabiliyetleri vardır. İkna ve iletişim becerileri yüksektir. Prestij ve güç peşinde olduklarından, başarıya ulaşmak ve önde olmak için rekabet içinde sürekli çalışır, kendilerini meşgul ederler. Bu meşguliyetten ve hedefe odaklanmalarından dolayı 
duygulardan ve değerlerden uzaklaşarak sahte benlik takınabilirler. Üçler için başarı, sevgi ve ilgiyi kendi üzerinde tutabilmek için bir araçtır.

Tip 4: Özgün, romantik, trajik, duyarlı, içe dönük, değişken ruh haline sahip dörtler, anlam aramaya yoğunlaşmış, mükemmeli aradıklarından eksiklik hissi yaşayabilir, hayata karşı olumsuz tavır içine girebilirler. Oldukça üretici, derin ve farklı bakış açılarından dolayı anlaşılamadıklarını hissedebilirler. Yanlış anlaşılma, diğer insanların sahip olduklarına sahip olamama, samimi olmayan tutumlar stres yaşamalarına sebep olabilir. Bununla beraber dört numaralar, hüznü ve melankoliyi bir çeşit motivasyon kaynağı olarak da kullanabilirler. Dörtler sevgi ve ilgiyi kendi üzerlerinde tutabilmek için farklılık stratejisini kullanırlar.

Tip 5: Beş numaralı kişilik tipleri, sorgulayan, gözlemci, zihinsel, sabırl1, meraklı, entelektüel ve analizci insanlardır. Kendilerini ve sahip olduklarını talepkâr durumlardan korumak için mesafeli ve cimri olabilirler. Beşler genel olarak özel hayatlarını özenle diğerlerinden uzak yaşamaya önem verebilirler. Biriktirme özellikleri olan beşler, bilgi sahibi olmaktan memnuniyet duyarlar. Sınırlarına müdahale edildiğinde, duygusal durumlarda ve aşırıya kaçılmasında stres yaşayabilirler. Güven tüm zihinsellerde olduğu gibi beşler için de son derece önemli bir kavramdır.

Tip 6: Altı numaralı kişilik tipleri için güven kelimesi anahtar bir kelimedir. Güvenilir olmak, güvenmek ve güvende olmak onların sürekli gözettikleri bir husustur. Güvenilir, sorumluluk sahibi, koruyucu, fedakâr, sadık olan altılar, sorgulayan bir zihne sahip olduklarından sezgisel, tedbirli, kuşkucu yapıları ile temkinli hareket ederek, tehlikeleri ve yanlışlıkları farkedebilirler. Otoriteyi koşulsuz kabul ile karşı çıkma tavrı takınabilirler. Belirsizlik ve güvensizlik ile karşılaştıklarında strese girip, şüphelerini netleştiremediklerinde agresif davranabilir, öfkeye kapılabilir ve saldırgan davranabilirler.

Tip 7: Özgürlüğüne düşkün, maceracı, yenilikçi, farklılı̆̆ı deneyimlemeye düşkün, dışa dönük, eğlenceli, iyimser olan yediler, odaklanmada problem yaşayabilir, çok yönlü aktif hayatlarından dolayı dikkatleri çabuk dağılabilir, sınırlardan kurtulmak ve özgürlüğü her açıdan deneyimlemek için aşırılığa kaçabilirler. Zihinsel olarak eğlenceli fikirler üretme, projeler oluşturma becerilerine sahip olsalar da eyleme geçmede, istikrar sağlamada ve sonuçlandırmada zorlanabilirler. Üzüntü, acı veren, sıkıcı ve rutin durumlardan uzaklaşma eğilimindedirler. Bu tür durumlar strese sebep olabilir, kısa süreli anlık öfkelenmeler yaşayabilirler.

Tip 8: Lider, dürüst, kendinden emin, koruyucu, güçlü, hükmedici olan sekizler, adalet ve haksızlıkları farkeder, çatışma durumlarında kaçınmadan ziyade eyleme geçebilirler. Güçlü ve korumacı tavırları ile çevrelerinin saygılarını kazanmaya önem verebilirler. Zayıflıktan, bağımlılıktan, itibar kaybetmekten ve belirsizlikten rahatsızlık duyabilirler. Haksızlıkları engelleyememek, duygularını kontrol edememek, samimiyetsizlik, sınırlar ve kurallar stres yaşamalarına sebep olabilir, öfkelerini açıkça ifade edebilir ya da intikam alabilirler.

Tip 9: İnsanların isteklerine duyarlı, farklılığa açık, empati kurabilen, rutine uyumlu, huzur ve sükunete önem veren dokuzlar, çatışmadan, rekabetten, belirsizlikten uzak durmak isterler. Zamanında karar almada, hayır diyebilmede, net tavır takınabilmede, değersizlik hissinde ve kontrol edilme durumunda strese girebilir, inatçı tavırları ile pasif saldırgan tutum sergileyebilirler.

\section{Araştırmanın Yöntemi}

\section{Örneklem}

Envanter geliştirme çalışması için üç farklı çalışma yapılmıştır. İlk çalışmada örneklem grubu kartopu örnekleme yöntemiyle belirlenmiştir. İkinci ve üçüncü çalışmada ise İstanbul Sabahattin Zaim Üniversitesi öğrencilerine kolayda örnekleme yöntemi ile ulaşlarak veriler toplanmıştır. 
Birinci çalışmada, ölçeğin faktör analizine tabi tutulmamış 113 soruluk denemelik formu ilk önce 340'ı kadın $(\% 54,6)$ ve 283 'ü Erkek $(\% 45,4)$ toplam 623 kişiye uygulanmıştır. Grubun yaşları 17 ile $62(24,64 \pm 7,6)$ arasında değişmektedir. Örneklemin 64’ü (\%11,9) lise; 19’u (\%3) yüksekokul; 481'i $(\% 77,2)$ üniversite; 43'ü $(\% 6,9)$ yüksek lisans; 6's1 (\%1) da doktora düzeyinde eğitim görmüştür. Örneklemin 143’ü (\%23) evli; 480’i (\%77) bekârdır.

İlk çalışmadan sonra yakınsak geçerlik ve yordama geçerliği çalışmaları yapılmıştır. Bu

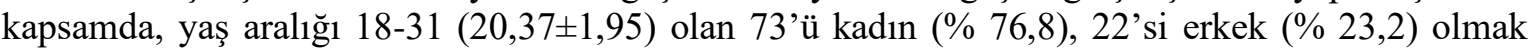
üzere toplam 95 kişilik bir öğrenci örnekleminde Enneagram Kişilik Envanteri ve CATI Kısa Form uygulanarak test tekrar test ve yakınsak geçerlik çalışmaları gerçekleştirilmiştir.

Son olarak 54 soruluk nihai form $310 \mathrm{kız}(\% 79,1)$ ve 82 Erkek $(\% 20,9)$ toplam 392 kişilik farklı bir örnekleme uygulanarak doğrulayıcı faktör analizi yapılmıştır. Bu ikinci grubun yaşı 17 ile 42 arasında $(20,99 \pm 2,96)$ değişmektedir. Yaş ortalaması ise 21 'dir. Örneklemin 376's1 $(\% 95,9)$ bekâr; 16's1 (\% 4,1) ise evli olduğunu bildirmiştir.

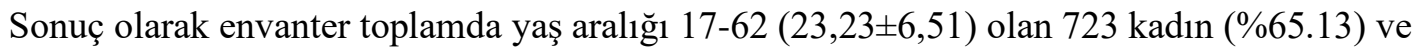
387 erkek (\%34.86) toplamda 1110 kişiye uygulanmıştır.

\section{Ölçeğin Geliştirme Süreci}

Ölçeğin geliştirilmesi sürecinde, öncelikle konuyla ilgili yerli ve yabancı literatür incelenmiş ve alanyazında geliştirilmiş ölçekler incelenerek madde havuzu hazırlanmıştır. Daha sonra, ölçme aracında ölçülecek enneagram tiplerinin özellikleri belirlenmiş ve belirlenen bu özelliklerin göstergesi olduğu düşünülen boyutları ölçmek amaciyla 125 soruluk madde havuzu oluşturulmuştur. Hazırlanan envanter Psikoloji, Rehberlik ve Psikolojik Danışmanlık bölümlerinden toplam 8 akademisyenin incelemelerine sunulmuş ve uzmanlardan gelen geri dönüşler doğrultusunda 12 soru denemelik madde havuzundan çıkarılmış ve 17 madde yeniden düzenlenmiştir. Bunlar yapılırken de Lawshe analizi yapılmıştır. Ardından denemelik maddeler gerçek çalışma grubuna uygulanmadan önce öğrenciler tarafindan tam olarak anlaşılıp anlaşılmadığını belirlemeye yönelik olarak rehberlik psikolojik danışmanlık ve aile danışmanlığı alanında yüksek lisans eğitimi yapan 47 öğrenciye ön deneme uygulaması yapılmıştır. Öğrencilerin verilen sorulara yaklaşık 40 dakikada cevap verdikleri ve anlamakta zorluk yaşadıkları bir maddenin bulunmadığı gözlenmiştir. Bu aşamadan sonra son halini alan madde havuzu 113 madde olarak şekillenmiş ve gerçek çalışma grubuna uygulanabilir hale getirilmiştir.

Uygulama öncesinde katılımcılar çalışma hakkında bilgilendirildikten sonra çalışmaya katılanlardan etik kurul onayına uygun bir şekilde bilgilendirilmiş onam formları kişilere verilmiş ve onayları alınmıştır. Katılımcıların sosyo-demografik özellikleriyle ilgili bir form ve Enneagram Ölçeği Türkçe formu (ETKE) verilmiştir. Araştırmanın etik onayı Sabahattin Zaim Üniversitesi Etik Kurulu'ndan alınmıştır.

Envanterdeki maddelerden tamamı olumlu önermelerden oluşmaktadır. Envanter, derecelendirmesi (1) Beni Hiç Tanımlamıyor, (2) Beni Biraz Tanımlıyor, (3) Beni Orta Derecede Tanımlıyor, (4) Beni Çok Fazla Tanımlıyor, (5) Tümüyle Beni Tanımlıyor şeklinde 5'li likert tipi ölçek şeklinde tasarlanmıştır. Geliştirilen maddeler rastgele sıralanmıştır.

\section{Kişisel Bilgi Formu}

Katılımcıların yaş, cinsiyet, eğitim düzeyi gibi demografik bilgilerin sorulduğu ve araştırmacı tarafından hazırlanan formdur.

\section{Enneagram Kişilik Envanteri Denemelik Form}

Araştırmacı tarafindan geliştirilen 113 soruluk Enneagram Kişilik Envanteri sorularından oluşan denemelik formdur. 


\section{Coolidge Eksen II Envanteri Plus Türkçe Formu Kısa Formu (CATI+TR KF)}

Coolidge (2006) tarafindan geliştirilen, DSM-5'te yer alan kişilik bozukluklarını ve diğer psikolojik bozuklukları ölçmek için geliştirilen Coolidge Eksen İki Envanteri Plus'un uzun formu 250 maddeden oluşan ve 1 (kesinlikle yanlış), 2 (Yanlışa yakın), 3 (Doğruya yakın) ve 4 (Kesinlikle doğru) şeklinde Likert tipi ölçeklendirilen bir öz-bildirim envanteridir. CATI+'ın uzun formunun Türkçe geçerlilik ve güvenilirlik çalışması yaş ortalaması 33.40 ( $\mathrm{Ss}=10.83$ ) olan 1286 kişilik toplum örneklemiyle yapılmıştır (Bilge, 2017). Coolidge Eksen II Envanteri Plus Türkçe Formu'nun (CATI+TR) DSM-5'teki kişilik bozukluklarını ölçen Türkiye'ye özgü kısa bir formu (CATI+TR KF) 648 kişilik toplum (\%49.8'i erkek, \% 50.2'si kadın ve yaş ortalaması $34.89 \pm 11.08$ ) ve 138 kişilik klinik (\%35.5'i erkek, \% 64.5'i kadın ve yaş ortalaması 31.01 10.03 ) olmak üzere iki örneklem kullanılarak geliştirilmiştir. CATI+TR KF Kişilik bozuklukları alt ölçeklerinin Cronbach alfa değerleri 0.66-0.77 arasında bulunmuştur. 43 kişilik öğrenci grubunda yapılan test-tekrar test analizinde korelasyon katsayıları 0.77-0.89 arasında bulunmuştur. Yakınsak ve ayırtedici geçerlik için CATI+TR KF ile birlikte toplum ve klinik örneklemlerden 106 kişiye SCID-II-Kişilik Anketi ve 107 kişiye Kişilik İnanç Ölçeği-Kısa Türkçe Form uygulanmıştır. Yakınsak geçerlik analizlerinde CATI+TR KF alt ölçeklerinin KİÖ-KTF alt ölçekleriyle korelasyon katsayıları 0.35-0.64 ve SCIDII-KA alt ölçekleri ile ise 0.27-0.78 arasında değişmektedir. Ayırt edici geçerlik analizinde CATI+TR KF kişilik bozuklukları puanlarının klinik örneklem lehine anlamlı derecede yüksek olduğu ve CATI+TR'nin klinik ve toplum örneklemini anlamlı düzeyde ayırt ettiği saptanmıştır (Bilge, 2018).

\section{Verilerin Analizi}

Değerlendirmeler sonucunda son şeklini alan envanter formun çalışma grubuna uygulanması sonucunda elde edilen veriler üzerinden ölçeğin geçerlik ve güvenirlik çalışmaları yapılmıştır. Veriler IBM-SPSS 25 veri analizi programına aktarılmıştır. Öncelikle Cronbach's Alpha güvenirlik katsayısı ve madde toplam korelasyonları hesaplanmıştır. Madde toplam korelasyon değerleri 0.30'un altında ve eksi değere sahip maddeler envanterden çıkartılmıştır (Özdamar, 2016, s. 53). Ardından kalan maddelerin faktör analizine uygunluğu Kaiser-Meyer-Olkin (KMO) ve Bartlett Küresellik Testleri ile incelenmiştir. KMO, veri setinin faktör analizi için uygun olup olmadığını, veri yapısının faktör çıkarma için uygun olup olmadığı hususunda bilgi vermektedir (Özdamar, 2016, s.150; Karagöz, 2016, s. 879). Bu testle birlikte maddelerin faktör analizine uygunluğu tespit edilmiş ve ardından ölçeğin yapı geçerliliğini belirlemek için açımlayıcı faktör analizi yapılmıştır. Açımlayıcı faktör analizi sonucunda literatüre uygun olarak yük değerleri. 30'dan düşük çıkan, faktör yük değerleri farklı faktörlerde birbirine yakın olan ve ayırt ediciliği düşük olan maddeler envanter dışında bırakılmıştır (Seçer, 2015, s. 87; Zeller \& Karmines, 1978). En nihayetinde ölçeğin güvenilirlik analizi kapsamında, iç tutarlılık için Cronbach alfa değerleri hesaplanmış, madde-toplam puan korelâsyonu ve ikiye bölme yöntemleri ile güvenirlik çalışmaları gerçekleştirilmiş ardından test-tekrar test güvenilirliği için Pearson momentler çarpımı korelasyon katsayısı ile ölçülerek raporlanmiştır.

\section{Bulgular \\ Ölçeğin Geçerliliği}

Geçerlik, bir ölçeğin neyi ne oranda doğru ölçtüğünü ortaya koyan değerdir. Bir ölçeğin geçerli sayılabilmesi için iç tutarlılığının yüksek olması ve geçerliliğinin sağlanması gerekmektedir (Büyüköztürk, 2002). Bu kapsamda Enneagram Türkiye Kişilik Envanteri’nin geçerliliği hususunda yapılan çalışmalar bu başlık altında raporlanmıştır.

\section{Kapsam Geçerliği}

Ölçülmek istenen davranışı (özelliği) ölçmede testi oluşturan maddelerin nicelik ve nitelik olarak yeterli olup olmadığı kapsam geçerliliği ile ortaya koyulmaktadır (Seçer, 2015, s.18). Bu kapsamda ölçeğin kapsam geçerliğini sağlamak amacıyla ilgili alanda çalışan akademisyenlere 
ulaşılarak uzman görüşüne başvurulmuştur. Bu kapsamda Din Psikolojisi, Eğitim Bilimleri Bölümü, Psikoloji Ana Bilim Dalı ile Psikolojik Danışma ve Rehberlik alanından 2 profesör, 2 doçent, 4 doktor öğretim üyesi olmak üzere toplam 8 farklı uzmanın görüşü alınmıştır. Uzman akademisyenlerin \%90'ının uygun bulduğu maddeler alınmış ve değiştirilmesi veya düzenlenmesi yönünde görüş bildirdikleri maddeler üzerinde de gereken düzenlemeler yapılmıştır. Kapsam geçerliğinin yanı sıra maddelerin dil bakımından uygunluğu ve anlaşılabilirliği, hedef kitleye uygunluğu amaciyla da uzman görüşleri de alınmış ve uzmanlardan gelen tavsiyeler doğrultusunda maddeler yeniden düzenlenmiştir.

Kapsam geçerlik oranları, Lawshe (1975) tarafindan geliştirilen ve bu nedenle Lawshe tekniği olarak bilinen teknikle belirlenmiştir. Lawshe tekniğinde, en az 5 en fazla ise 40 uzman görüşüne ihtiyaç bulunmaktadır. Bizim çalışmamızda uzmanlara hazırlanan soru havuzu yollanmış ve yollanan ifadelerde "Kaldırılmalı (1); Revize Edilmeli (2); Kalmalı (3)" şeklinde üç seçenek verilmiştir.

Lawshe tekniğinde kapsam geçerlik oranları (KGO), herhangi bir maddeye ilişkin "Gerekli" görüşünü belirten uzman sayısının, maddeye ilişkin görüş belirten toplam uzman sayısına oranının 1 eksiği ile elde edilir. Buna göre; uzmanların yarısı maddeye ilişkin "Gerekli" şeklinde görüş bildirdiklerinde $\mathrm{KGO}=0$, yarsından fazlası" "Gerekli" şeklinde görüş bildirmiş ise $\mathrm{KGO}>0$ ve uzmanların yarısından fazlası" "Gerekli" şeklinde görüş bildirmemiş ise $\mathrm{KGO}<0$ olacaktır. Bu analizde bir de kapsam geçerlik indeksi (KGI) hesaplanmaktadır. Kapsam geçerlik indeksi (KGi), $\alpha=0,05$ düzeyinde anlamlı olan ve nihai forma alınacak maddelerin toplam KGO ortalamalar üzerinden elde edilir. Araştırmamızda toplam 8 uzmandan görüş alınmıştır. Analiz sonucunda KGO değeri $0,79, \mathrm{KGİ}$ ise 0,87 olarak tespit edilmiştir.

\section{Yapı Geçerliliği}

Ölçeğin yapı geçerliği çalışması için öncelikle denemelik formdaki maddelerin madde analizi ve güvenirlik analizi yapılmıştır. Bu kapsamda, ölçek belirtici istatistikleri, veri yapısına uygun olarak güvenirlik katsayısı (Cronbach Alfa), soru silinirse güvenirlik katsayısı ve madde toplam korelasyonu gibi değerler incelenmiştir. Madde toplam korelasyonu test maddelerinden alınan puanlar ile testin toplam puanı arasındaki ilişkiyi açıklamaktadır. Madde-toplam korelâsyonunun yüksek olması, maddelerin benzer davranışları ölçtüğünü ve testin iç tutarlılığının yüksek olduğunu göstermektedir. Genel olarak, madde-toplam korelâsyonu 0,25 ve daha yüksek olan maddelerin bireyleri iyi derecede ayırt ettiği söylenebilir (Karagöz, 2016, s. 947; Büyüköztürk, 2002, s.118-119). Bununla birlikte ölçeğin madde toplam korelasyonu 0,10 ve altında olan maddeler ile aralarında ters korelasyon olan maddelerin envanterden çıkarılmasının uygun olacağını belirten uzmanlar (Özdamar, 2016, s. 76-128) ile madde toplam korelasyon değerleri sıfira çok yakın olan maddelerin envanterden çıkarılmasının daha öncelikli bir seçenek olabileceğini ifade eden uzmanlar da bulunmaktadır (Seçer, 2015, s. 64). Bu analizde ayrıca madde silinirse ölçeğin güvenirlik katsayılarındaki (Cronbach's Alpha if item deleted) değişimleri de incelenmektedir. Envanterden madde silindiğinde Cronbach Alfa katsayısındaki \% 5'ten daha fazla artış olması halinde o maddenin envanterden çıkarılmasının uygun olacağına karar verilebilir (Özdamar, 2016, s. 128). Bu bilgiler kapsamında yapılan madde analizinde ölçeğin güvenirliğine ilişkin olarak elde edilen iç tutarlılık analizi sonucunda Cronbach's Alpha değeri $\alpha=0,838$ olduğu görülmüştür. Bu değer ilk uygulama sonrasında ölçeğin yeterli iç tutarlığa sahip olduğu şeklinde değerlendirilebilir. İç tutarlılık değerinin yeterli olduğunun tespit edilmesinin ardından madde analizleri için elde edilen çıktılar üzerinde yer alan "Düzeltilmiş Madde-Toplam Korelasyonu (Corrected Item-Total Correlation)" ve "Madde Silinirse Ölçeğin Güvenirlik Katsayısı (Cronbach's Alpha if Item Deleted)" sütunları incelenmiştir.

Madde-toplam korelasyon değerlerine göre değeri 0.20 ve altında olan maddeler ile negatif korelasyon gösteren maddeler envanterden çıkarılmıştır. Bu sorular çıkarıldıktan sonra yapılan analizde Cronbach's Alpha değeri a= 0,854 olarak tespit edilmiştir. Analiz sonucunda madde-toplam 
korelasyon sonuçlarına göre 0.20 'nin altında değere sahip olan madde olmadığı, madde çıkarıldığında güvenirlik katsayısının değişim oranını $\% 5$ ve üzerinde değiştirebilecek bir madde olmadığı gözlenmiştir. Sonuç olarak teste katkısı düşük olduğu belirlenen maddeler testten çıarılmış ve 105 madde ile analizlere devam edilmesine karar verilmiştir.

Madde güvenilirlik analizinden sonra ölçeğin faktör analizine uygunluğunu tespit etmek Kaiser-Meyer-Olkin (KMO) katsayısı hesaplanmış ve Barlett Spehericity testi yapılmıştır. KMO, veri setinin faktör analizi için uygun olup olmadığını, veri yapısının faktör çıkarma için uygun olup olmadığı hususunda bilgi vermektedir (Karagöz, 2016, s. 879). KMO değerleri ölçekteki bir değişkenin değerinin diğer değişkenler tarafindan yeterli düzeyde tahmin edilip edilemediğini ortaya koymaktadır. Ölçeğin KMO örneklem yeterliliği ölçütüne göre çok iyi bir düzeyde olduğu ve Bartlett testi'ne göre anlamlılık düzeylerinin $\mathrm{p}=0,00<0.01$ olduğu görülmüştür (KMO=0.819; Aprprox. Chi Square 6806,653; $\mathrm{df}=1128 ; \mathrm{p}=0,00$ ).

Envanterdeki maddelerin faktör analizine uygunluğu tespit edildikten sonra envanterin yap1 geçerliliğini ortaya koymak için elde edilen verilere açımlayıcı faktör analizi (exploratory factor analysis) yapılmıştır. Faktör analizinde madde seçiminde faktör yük değeri ve iki faktör yükü arasındaki fark dikkate alınmış ve faktör yük değeri 0.30 ve üstü olan ve yüksek iki faktör yükü arasındaki farkı en az 0.10 olan maddeler ölçeğe alınmıştır (Büyüköztürk, 2007). Ölçeğimiz toplam puan indeksli bir envanter olmayıp MMPI gibi bir profil envanteri olduğu için, her alt ölçek kendi içinde faktör analizine tabi tutulmuştur. Ayrıca Varimax döndürmesi yapılarak her alt ölçeğin kaç faktörlü bir yapı gösterdiği değerlendirilmiştir. Yapılan analizde tek faktör altında toplanan, Eiegen değerleri 1'in üzerinde olan ve tek faktör altında toplanan sorular kabul edilerek envanter alt ölçekleri oluşturulmuştur. Alt ölçeklerin faktör yapıları, faktör yükleri ve varyans oranları Tablo 1'de sunulmuştur.

Tablo 1: Enneagram Türkiye Kişilik Envanteri'nin Alt Faktör Dağılımları

\begin{tabular}{|c|c|c|c|}
\hline 1 (Bir) Numaralı Kişilik Motifi & Faktör Yükü & E. V. & Top. V \% \\
\hline E87 & 0,815 & \multirow{7}{*}{2,89} & \multirow{7}{*}{$\% 48,25$} \\
\hline E26 & 0,734 & & \\
\hline E64 & 0,707 & & \\
\hline E79 & 0,655 & & \\
\hline E31 & 0,632 & & \\
\hline E113 & 0,603 & & \\
\hline E87 & 0,815 & & \\
\hline 2 (İki) Numaralı Kişilik Motifi & Faktör Yükü & Eigen Value & Top. V \% \\
\hline E59 & 0,754 & \multirow{6}{*}{2,24} & \multirow{6}{*}{$\% 37,44$} \\
\hline E34 & 0,688 & & \\
\hline E50 & 0,628 & & \\
\hline E60 & 0,556 & & \\
\hline E55 & 0,536 & & \\
\hline E93 & 0,463 & & \\
\hline 3 (Üç) Numaralı Kişilik Motifi & Faktör Yükü & Eigen Value & Top. V \% \\
\hline E49 & 0,695 & \multirow{6}{*}{2,0} & \multirow{6}{*}{$\% 51,6$} \\
\hline E38 & 0,670 & & \\
\hline E54 & 0,651 & & \\
\hline E89 & 0,531 & & \\
\hline E68 & 0,374 & & \\
\hline E13 & 0,366 & & \\
\hline 4 (Dört) Numaralı Kişilik Motifi & Faktör Yükü & Eigen Value & Top. V \% \\
\hline
\end{tabular}




\begin{tabular}{|c|c|c|c|}
\hline E91 & 0,668 & \multirow{6}{*}{2,9} & \multirow{6}{*}{$\% 48,7$} \\
\hline E33 & 0,575 & & \\
\hline E29 & 0,561 & & \\
\hline E85 & 0,543 & & \\
\hline E28 & 0,487 & & \\
\hline E94 & 0,434 & & \\
\hline 5 (Beş) Numaralı Kişilik Motifi & Faktör Yükü & Eigen Value & Top. V \% \\
\hline E5 & 0,669 & \multirow{6}{*}{3,1} & \multirow{6}{*}{$\% 53,25$} \\
\hline E106 & 0,667 & & \\
\hline E9 & 0,662 & & \\
\hline E95 & 0,548 & & \\
\hline E100 & 0,527 & & \\
\hline E92 & 0,495 & & \\
\hline 6 (Altı) Numaralı Kişilik Motifi & Faktör Yükü & Eigen Value & Top. V \% \\
\hline E11 & 0,734 & \multirow{6}{*}{2,01} & \multirow{6}{*}{$33,65 \%$} \\
\hline E101 & 0,636 & & \\
\hline E10 & 0,620 & & \\
\hline E102 & 0,552 & & \\
\hline E80 & 0,501 & & \\
\hline E90 & 0,368 & & \\
\hline 7 (Yedi) Numaralı Kişilik Motifi & Faktör Yükü & Eigen Value & Top. V \% \\
\hline E30 & 0,646 & \multirow{6}{*}{1,76} & \multirow{6}{*}{$29,35 \%$} \\
\hline E78 & 0,587 & & \\
\hline E51 & 0,561 & & \\
\hline E111 & 0,533 & & \\
\hline E24 & 0,481 & & \\
\hline $\mathbf{E 3 5}$ & 0,411 & & \\
\hline 8 (Sekiz) Numaralı Kişilik Motifi & Faktör Yükü & Eigen Value & Top. V \% \\
\hline E88 & 0,703 & \multirow{6}{*}{2,5} & \multirow{6}{*}{$\% 41,66$} \\
\hline E20 & 0,668 & & \\
\hline E21 & 0,660 & & \\
\hline E27 & 0,653 & & \\
\hline E43 & 0,629 & & \\
\hline E72 & 0,549 & & \\
\hline 9 (Dokuz) Numaralı Kişilik Motifi & Faktör Yükü & Eigen Value & Top. V \% \\
\hline E105 & 0,718 & \multirow{6}{*}{2,8} & \multirow{6}{*}{$\% 47,61$} \\
\hline E76 & 0,713 & & \\
\hline E52 & 0,684 & & \\
\hline E8 & 0,459 & & \\
\hline E40 & 0,751 & & \\
\hline E46 & 0,717 & & \\
\hline
\end{tabular}

E.V.: Eiegen Value; Top.V.: Toplam varyans; M.: Madde numarasl

Tablo 1 incelendiğinde ölçeğin 9 alt faktör altında almıș oldukları faktör yüklerinin 0.30 üzerinde olduğu görülmektedir.

Ölçeğin açımlayıcı faktör analizi neticesinde oluşan alt faktörler ve envanter toplamı açısından güvenirliğin hesaplanması için Cronbach Alpha değerleri ile birlikte Guttman ve İç tutarlılığın belirlenmesinde envanterde yer alan maddelerin kişileri ne kadar ayırt ettiğini incelemek amacıyla testin eşit iki yarıya ayrılması ile hesaplanan Spearman-Brown iç tutarlılık katsayıları 
hesaplanmıştır. Ölçeğin 54 maddesinin ilk uygulamasında Cronbach's Alpha değeri 0,805; Guttman güvenirlik katsayıs1 0,852; Spearman Brown katsayısı ise 0,790'dir. $\mathrm{KMO}=0,819(\mathrm{p}<0,01)$ olarak bulunmuştur.

Tablo 2: Envanter Alt Ölçeklerine Dair Birinci ve İkinci Çalışmada Elde Edilen Güvenirlik

Değerleri

\begin{tabular}{lcccccc}
\hline EKÖ-TR Alt Ölçekler & \multicolumn{3}{c}{$\begin{array}{c}\text { Birinci Çalışma } \\
(\mathbf{N = 6 2 3 )}\end{array}$} & \multicolumn{3}{c}{$\begin{array}{c}\text { İkinci Çalışma } \\
(\mathbf{N = 3 9 2 )}\end{array}$} \\
\cline { 2 - 8 } & $\begin{array}{c}\text { Madde } \\
\text { Sayısı }\end{array}$ & Ort \pm SS & Alfa $(\alpha)$ & $\begin{array}{c}\text { Madde } \\
\text { Sayısı }\end{array}$ & Ort \pm SS & Alfa $(\alpha)$ \\
\hline 1 Numaralı Kişilik Tipi & 6 & $3,59 \pm 0,77$ & 0,78 & 6 & $3,62 \pm 0,80$ & 0,91 \\
\hline 2 Numaralı Kişilik Tipi & 6 & $3,98 \pm 0,56$ & 0,64 & 6 & $3,90 \pm 0,66$ & 0,74 \\
\hline 3 Numaralı Kişilik Tipi & 6 & $3,60 \pm 0,60$ & 0,61 & 6 & $3,55 \pm 0,68$ & 0,70 \\
\hline 4 Numaralı Kişilik Tipi & 6 & $3,36 \pm 0,65$ & 0,62 & 6 & $3,36 \pm 0,72$ & 0,70 \\
\hline 5 Numaralı Kişilik Tipi & 6 & $3,72 \pm 0,57$ & 0,62 & 6 & $3,61 \pm 0,67$ & 0,79 \\
\hline 6 Numaralı Kişilik Tipi & 6 & $3,75 \pm 0,54$ & 0,60 & 6 & $3,72 \pm 0,63$ & 0,78 \\
\hline 7 Numaralı Kişilik Tipi & 6 & $3,68 \pm 0,71$ & 0,60 & 6 & $3,55 \pm 0,78$ & 0,79 \\
\hline 8 Numaralı Kişilik Tipi & 6 & $3,33 \pm 0,56$ & 0,71 & 6 & $3,19 \pm 0,61$ & 0,73 \\
\hline 9 Numaralı Kişilik Tipi & 6 & $3,98 \pm 0,48$ & 0,66 & 6 & $3,91 \pm 0,56$ & 0,72 \\
\hline
\end{tabular}

Tablo 2 incelendiğinde, alt ölçeklerden güvenirliğin en düşük 7 ve 6 numaralı kişilik tipi alt ölçeğinde $(0,60)$, en yüksek ise 1 numaralı Kişilik Tipi Alt ölçeğinde $(0,78)$ olduğu anlaşılmaktadır $(\mathrm{N}=623)$. Yine ikinci çalışma değerleri incelendiğinde en düşük 3 ve 4 numaralı kişilik tipi alt ölçeklerinde $(0,70)$, en yüksek ise 1 numaralı Kişilik Tipi Alt ölçeğinde $(0,91)$ olduğu anlaşılmaktadır $(\mathrm{N}=392)$. İkinci çalışmada ölçek güvenirliğinin tüm alt faktörlerde anlamlı şekilde iyileştiği anlaşılmaktadır.

Envanterin açımlayıcı faktör analizinden sonra, örneklemin envanter alt ölçekleri arasındaki korelasyon değerleri hesaplanmış ve aşağıda Tablo 5'de raporlanmıştır. 
Tablo 3: Birinci Çalışmada Alt Faktörler Arasındaki Korelasyon Değerleri

\begin{tabular}{|c|c|c|c|c|c|c|c|c|c|c|}
\hline & & Tip_1 & Tip_2 & Tip_3 & Tip_4 & Tip_5 & Tip_6 & Tip_7 & Tip_8 & Tip_9 \\
\hline \multirow[t]{2}{*}{ Tip_1 } & $r$ & 1,00 &, $163^{\text {** }}$ &, $289^{* *}$ & ,099* &, $442^{* *}$ &, $532^{* *}$ & 0,03 &, $198^{* * *}$ & $-0,02$ \\
\hline & $\mathrm{p}$ & & 0,00 & 0,00 & 0,01 & 0,00 & 0,00 & 0,48 & 0,00 & 0,59 \\
\hline \multirow[t]{2}{*}{ Tip_2 } & $r$ &, $163^{* *}$ & 1,00 &, $317^{* *}$ &, $282^{* *}$ &, $142^{* *}$ &, $272^{* *}$ &, $188^{* * *}$ & ,079* &, $489^{* *}$ \\
\hline & $\mathrm{p}$ & 0,00 & & 0,00 & 0,00 & 0,00 & 0,00 & 0,00 & 0,05 & 0,00 \\
\hline \multirow[t]{2}{*}{ Tip_3 } & $\mathrm{r}$ &, $289^{* *}$ &, $317^{* *}$ & 1,00 &, $321^{* *}$ &, $345^{* *}$ &, $341^{* * *}$ &, $458^{* *}$ &, $506^{* *}$ &, $159^{* *}$ \\
\hline & $\mathrm{p}$ & 0,00 & 0,00 & & 0,00 & 0,00 & 0,00 & 0,00 & 0,00 & 0,00 \\
\hline \multirow[t]{2}{*}{ Tip_4 } & $\mathrm{r}$ & ,099* &, $282^{* *}$ &, $321^{* *}$ & 1,00 &, $357^{* * *}$ &, $278^{* *}$ &, $280^{* * *}$ &, $186^{* * *}$ &, $262^{* * *}$ \\
\hline & $\mathrm{p}$ & 0,01 & 0,00 & 0,00 & & 0,00 & 0,00 & 0,00 & 0,00 & 0,00 \\
\hline \multirow[t]{2}{*}{ Tip_5 } & $r$ &, $442^{* *}$ &, $142^{* *}$ &, $345^{* *}$ &, $357^{* *}$ & 1,00 &, $616^{* * *}$ &, $234^{* *}$ &, $218^{* *}$ &, $142^{* *}$ \\
\hline & $\mathrm{p}$ & 0,00 & 0,00 & 0,00 & 0,00 & & 0,00 & 0,00 & 0,00 & 0,00 \\
\hline \multirow[t]{2}{*}{ Tip_6 } & $\mathrm{r}$ &, $532^{* *}$ &, $272^{* *}$ &, $341^{* *}$ &, $278^{* * *}$ &, $616^{* *}$ & 1,00 &, $174^{* *}$ &, $228^{* *}$ &, $146^{* *}$ \\
\hline & $\mathrm{p}$ & 0,00 & 0,00 & 0,00 & 0,00 & 0,00 & & 0,00 & 0,00 & 0,00 \\
\hline \multirow[t]{2}{*}{ Tip_7 } & $\mathrm{r}$ & 0,03 &, $188^{* *}$ &, $458^{* *}$ &, $280^{* * *}$ &, $234^{* * *}$ &, $174^{* *}$ & 1,00 &, $421^{* *}$ &, $178^{* * *}$ \\
\hline & $\mathrm{p}$ & 0,48 & 0,00 & 0,00 & 0,00 & 0,00 & 0,00 & & 0,00 & 0,00 \\
\hline \multirow[t]{2}{*}{ Tip_8 } & $\mathrm{r}$ &, $198^{* *}$ &, $079^{*}$ &, $506^{* *}$ &, $186^{* *}$ &, $218^{* * *}$ &, $228^{* *}$ &, $421^{\text {** }}$ & 1,00 & 0,07 \\
\hline & $\mathrm{p}$ & 0,00 & 0,05 & 0,00 & 0,00 & 0,00 & 0,00 & 0,00 & & 0,09 \\
\hline \multirow[t]{3}{*}{ Tip_9 } & $\mathrm{r}$ & $-0,02$ &, $489^{* *}$ &, $159^{* *}$ &, $262^{* * *}$ &, $142^{\text {** }}$ &, $146^{* * *}$ &, $178^{* *}$ & 0,07 & 1,00 \\
\hline & $\mathrm{p}$ & 0,59 & 0,00 & 0,00 & 0,00 & 0,00 & 0,00 & 0,00 & 0,09 & \\
\hline & $\mathrm{N}$ & 623,00 & 623,00 & 623,00 & 623,00 & 623,00 & 623,00 & 623,00 & 623,00 & 623,00 \\
\hline
\end{tabular}

Tablo incelendiğinde genel olarak envantere ait alt ölçekler arasında anlamlı korelatif ilişki olduğu yalnızca Faktör 1 ile Faktör 8 ve Faktör 4 arasında; Faktör 5 ile Faktör 8 arasında ve Faktör 7 ile Faktör 6 arasında anlamlı bir korelatif ilişki gözlenmemiştir $(\mathrm{p}<0.05)$.

\section{Yakınsak Geçerlik Çalıșması}

Yakınsak geçerlik ve yordama geçerliği çalışmaları, yaș aralığ $18-31(20,37 \pm 1,95)$ olan 73 'ü kadın (\% 76,8), 22 'si erkek (\% 23,2) olmak üzere toplam 95 kişilik bir öğrenci örnekleminde Enneagram Kişilik Envanteri ve CATI Kısa Form uygulanarak gerçekleştirilmiştir. 
Tablo 4: Enneagram Kişilik Tipleri ve CATI+TR KF Kişilik Bozuklukları Alt Ölçekleri Arasındaki Yakınsak Geçerlik Korelasyon Katsayıları

\begin{tabular}{lccccccccc}
\hline & Tip1 & Tip2 & Tip3 & Tip4 & Tip5 & Tip6 & Tip7 & Tip8 & Tip9 \\
\hline Paranoid &, $45^{* *}$ &, 11 &, $36^{* *}$ &, 04 &, $31^{* *}$ &, $33^{* *}$ &, $29^{* *}$ &, $48^{* *}$ &, 18 \\
\hline Şizotipal &, 11 &,- 05 &, 13 &, $28^{* *}$ &, $22^{*}$ &, 15 &, 16 &, $31^{* *}$ &,- 01 \\
\hline Şizoid &, 08 &,$- 25^{*}$ &,- 05 &, 03 &, 04 &, 04 &,- 09 &, 01 &,- 15 \\
\hline Antisosyal &, 11 &,$- 38^{* *}$ &, 09 &,- 06 &, 07 &, 04 &, $30^{* *}$ &, $23^{*}$ &,$- 25^{*}$ \\
\hline Borderline &, $28^{* *}$ &, 15 &, 10 &, 19 &, 05 &, $23^{*}$ &, $31^{* *}$ &, $23^{*}$ &, $22^{*}$ \\
\hline Histriyonik &, $31^{* *}$ &, 06 &, $31^{* *}$ &, $23^{*}$ &, $27^{* *}$ &, $20^{*}$ &, $41^{* *}$ &, $42^{* *}$ &, 16 \\
\hline Narsisistik &, $53^{* *}$ &, 03 &, $42^{* *}$ &, 17 &, $42^{* *}$ &, $26^{*}$ &, $35^{* *}$ &, $32^{* *}$ &, 11 \\
\hline Okkb &, $46^{* *}$ &, 03 &, $27^{* *}$ &, 09 &, $29^{* *}$ &, $29^{* *}$ &, $20^{*}$ &, $29^{* *}$ &, 09 \\
\hline Çekingen &, 15 &, 04 &,$- 28^{* *}$ &,- 03 &, 02 &,- 02 &,- 03 &,$- 34^{* *}$ &, 02 \\
\hline Bağımlı &, $21^{*}$ &, 13 &,$- 20^{*}$ &,- 08 &,- 04 &, 07 &, 04 &,- 16 &, 06 \\
\hline
\end{tabular}

Tablo 4 incelendiğinde Enneagram Kişilik Tipleri ve CATI+TR KF Kişilik Bozuklukları alt ölçekleri arasında yapılan korelasyon analizleri sonucunda Enneagram kişilik tipleri ile kişilik bozuklukları arasında pozitif ve negatif yönde farklı kombinasyonlarda anlamlı düzeyde korelasyon katsayıları gözlenmektedir $(\mathrm{p}<0.05)$.

\section{Doğrulayıcı Faktör Analizine İlişkin Bulgular}

Envanterin faktör yapısının sonraki ölçümlerde korunup korunmadığının anlaşılması amaciyla $310 \mathrm{kız}(\% 79,1)$ ve 82 Erkek $(\% 20,9)$ toplam 392 kişilik bir örneklemden elde edilen veriler doğrulayıcı faktör analizine tabi tutularak uyum değerleri ve modifikasyon indeksleri incelenmiştir. Uyum indekslerinde gözlenen ve gizil değişkenler arasındaki kovaryansa bakarak modele ilişkin önerilen modifikasyonlar uygulanmıştır. Analiz sonucunda uyum değerleri [ $(\chi 2(2545,804, \mathrm{sd}=1027$, $\mathrm{p}=.000) ; \chi^{2} / \mathrm{sd}=2,47 ; \mathrm{RMSEA}=0.06 ; \mathrm{SRMR}=0.07 ; \mathrm{GFI}=0.97 ; \mathrm{AGFI}=0.94 ; \mathrm{CFI}=0.92 ; \mathrm{IFI}=0,92 ;$ $\mathrm{NFI}=0.91 ; \mathrm{RFI}=0.87$ ] olarak tespit edilmiştir.

Tablo 5: Model Uyumuna İlişkin Kabul Edilebilir İndeks Değerleri

\begin{tabular}{lll}
\hline Uyum Ölçüleri & İyi Uyum Değerleri & $\begin{array}{l}\text { Kabul Edilebilir Uyum } \\
\text { Değerleri }\end{array}$ \\
\hline RMSEA & $0.00<$ RMSEA $<0.05$ & $0.05<$ RMSEA $<0.10$ \\
\hline SRMR & $0.00<$ SRMR $<0.05$ & $0.05<$ SRMR $<0.10$ \\
\hline RMR & $0.00<$ SRMR $<0.05$ & $0.05<$ SRMR $<0.10$ \\
\hline GFI & $0.95<$ GFI $<1.00$ & $0.90<\mathrm{GFI}<0.95$ \\
\hline AGFI & $0.90<$ AGFI $<1.00$ & $0.85<\mathrm{AGFI}<0.90$ \\
\hline NFI & $0.95<\mathrm{NFI}<1.00$ & $0.90<\mathrm{NFI}<0.95$ \\
\hline CFI & $0.95<\mathrm{CFI}<1.00$ & $0.90<\mathrm{CFI}<0.95$ \\
\hline RFI & $0.90<\mathrm{RFI}<1.00$ & $0.85<\mathrm{RFI}<0.90$ \\
\hline
\end{tabular}

Envanterin tüm alt faktörlerinin DFA uyum indeksleri de incelenmiş ve ayrı ayrı Tablo 6' da raporlanmıştır. 
Tablo 6: Envanter Model Uyumu İndeks Değerleri

\begin{tabular}{cccccccccc}
\hline $\begin{array}{c}\text { Uyum } \\
\text { Ölçütleri }\end{array}$ & Tip 1 & Tip 2 & Tip 3 & Tip 4 & Tip 5 & Tip 6 & Tip 7 & Tip 8 & Tip 9 \\
\hline SRMR &, 04 &, 04 &, 06 &, 06 &, 05 &, 09 &, 05 &, 06 &, 04 \\
\hline RMSEA &, 08 &, 06 &, 10 &, 09 &, 09 &, 04 &, 07 &, 10 &, 05 \\
\hline RMR &, 05 &, 03 &, 07 &, 07 &, 05 &, 07 &, 05 &, 08 &, 05 \\
\hline GFI &, 98 &, 98 &, 97 &, 97 &, 97 &, 94 &, 98 &, 95 &, 99 \\
\hline AGFI &, 95 &, 96 &, 93 &, 93 &, 94 &, 85 &, 96 &, 88 &, 97 \\
\hline NFI &, 96 &, 93 &, 91 &, 99 &, 98 &, 93 &, 93 &, 95 &, 90 \\
\hline CFI &, 97 &, 95 &, 94 &, 92 &, 90 &, 94 &, 97 &, 97 &, 92 \\
\hline RFI &, 93 &, 89 &, 89 &, 85 &, 90 &, 94 &, 92 &, 86 &, 91 \\
\hline
\end{tabular}

Tablo 6 incelendiğinde $\chi 2$ sd oran1, RMSEA, SRMR, RMR, NFI, CFI ve RFI değerlerinin kabul edilebilir uyum GFI ve AGFI değerlerinin iyi uyum değerleri gösterdiği anlaşılmaktadır (Özdamar, 2016, s. 185). Doğrulayıcı faktör analizinin bağlantı diyagramı (path diagram) Şekil 2'de yer almaktadir. 


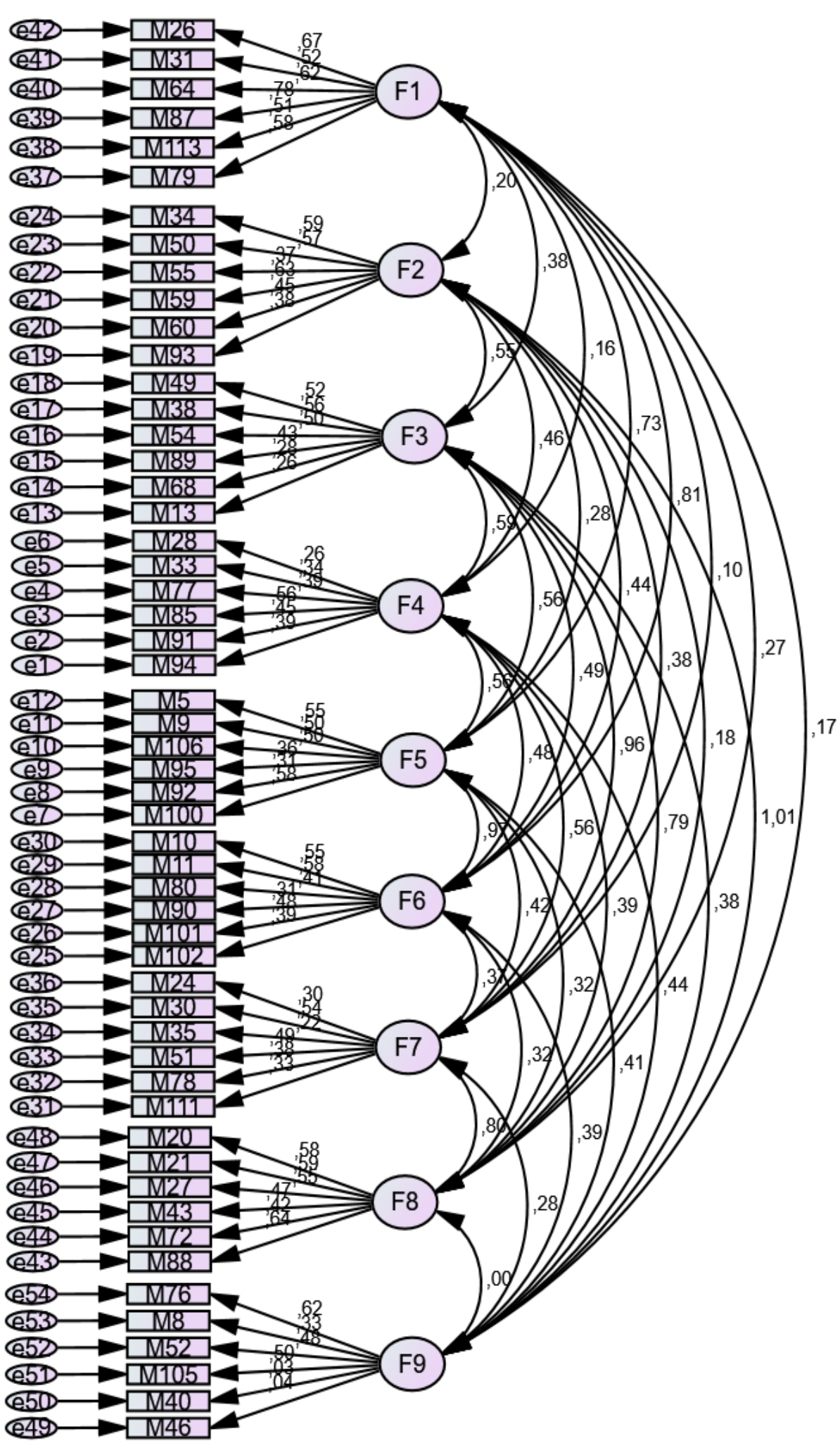

Şekil 2: Enneagram Kişilik Envanteri Birinci Düzey DFA Diyagramı 


\section{Tartışma, Sonuç Ve Öneriler}

Enneagram Türkiye Kişilik Envanteri'nin geliştirme sürecinde, ölçeğin geçerlik ve güvenirlik çalışmaları yapılmış ve raporlanmıştır. Ölçeğin kapsam geçerliği kapsamında lawshe analizi yapılmış olup analiz sonucunda KGO değeri $0,79, \mathrm{KGI}$ ise 0,87 olarak tespit edilmiştir. Buna göre, $\alpha=0,05$ anlamlılık düzeyinde KGO minimum değeri 8 uzman için 0.75 olarak literatürde belirtildiğinden (Ayre ve Scally, 2014) uzman görüşleri neticesinde elde ettiğimiz envanter maddelerinin kapsam geçerliğini sağladığı anlaşılmaktadır. Elde edilen KGİ değerinin KGÖ değerinden büyük olması (KGI $>$ KGÖ) ölçekte kalan maddelerinin kapsam geçerliğinin istatistiksel olarak anlamlı olduğunu gösterir (Lawshe 1975).

Envanter 3 farklı çalışma ile test edilmiş, ilk çalışmada 113 soruluk madde havuzu deneklere uygulanmış ve açımlayıcı faktör analizi neticesinde 54 maddelik ve 9 alt boyutluk nihai form elde edilmiştir. Ölçeğin faktör analizi öncesi KMO örneklem yeterliliği ölçütüne göre çok iyi bir düzeyde olduğu ve Bartlett testi'ne göre anlaml1lik düzeylerinin $\mathrm{p}=0,00<0.01$ olduğu görülmüştür $(\mathrm{KMO}=0.819$; Aprprox. Chi Square 6806,653; $\mathrm{df}=1128 ; \mathrm{p}=0,00)$. Yapılan analizde tek faktör altında toplanan, Eiegen değerleri 1'in üzerinde olan ve toplam varyansın çoğunluğunu açıklayan faktörler alınarak, her profil kendi içerisinde analiz edilmiştir. Bu bağlamda envanter enneagram kişilik teorisine göre 9 alt faktöre sahip bir envanter olarak geliştirilmiştir. Envanterde toplam puan alınmamaktadır. Envanterde ters madde bulunmamaktadır.

Envanterin birinci uygulamasında 54 maddesinin Cronbach's Alpha değeri 0,80; Guttman güvenirlik katsayıs1 0,85; Spearman Brown katsayısı ise 0,79'dur. Envanter $p<0,01$ düzeyinde anlamlı madde ayırdedicilik özelliğine; $\mathrm{p}<0.01$ düzeyinde anlamlı madde toplam korelasyonuna sahiptir. Ölçeğin üçüncü ve nihai uygulamasında ise 54 maddenin Cronbach's Alpha değeri 0,89; Guttman güvenirlik katsayıs1 0,92; Spearman Brown katsayıs1 ise 0,82'dir. Envanter $\mathrm{p}<0,01$ düzeyinde anlamlı madde ayırdedicilik özelliğine; $\mathrm{p}<0.01$ düzeyinde anlamlı madde toplam korelasyonuna sahip olduğu gözlenmiştir.

Yakınsak geçerlik analizi kapsamında Enneagram Kişilik Tipleri ve CATI+TR KF Kişilik Bozuklukları alt ölçekleri arasında yapılan korelasyon analizleri sonucunda Enneagram kişilik tipleri ile kişilik bozuklukları arasında pozitif ve negatif yönde farklı kombinasyonlarda anlamlı düzeyde korelasyon katsayıları bulunmuştur $(\mathrm{p}<0.05)$. Ölçeğin test tekrar test analizinde korelasyon katsayıları 0.20 ile 0.57 arasında gözlenmiştir. Ölçeğin ikinci ve nihai çalışmasında tüm alt faktörlerde anlamlı bir korelatif ilişki olduğu tespit edilmiştir $(\mathrm{p}<0,01)$.

Envanterin yap1 geçerliği bağlamında üçüncü ve son çalışmada elde edilen verilere doğrulayıcı faktör analizi (DFA) yapılmış ve uyum indeksleri incelenmiştir. Bu kapsamda tüm alt ölçeklerin ayrı ayrı uyum indeksleri incelenmiş ve raporlanmıştır. Bu değerler incelendiğinde envanterin tüm alt ölçeklerinde uyum indekslerinin referans değerler içerisinde olduğu ve kabul edilebilir indeks değerler içerisinde olduğu anlaşılmıştır. Bununla birlikte envanterin tüm alt ölçekleri arasındaki kovaryansa bakarak modele ilişkin önerilen modifikasyonlar da incelenmiştir. Analiz sonucunda uyum değerleri [ $(\chi 2(2545,804, \mathrm{sd}=1027, \mathrm{p}=.000) ; \chi 2 / \mathrm{sd}=2,47$; RMSEA $=0.06$; $\mathrm{SRMR}=0.07 ; \mathrm{GFI}=0.97 ; \mathrm{AGFI}=0.94 ; \mathrm{CFI}=0.92 ; \mathrm{IFI}=0,92 ; \mathrm{NFI}=0.91 ; \mathrm{RFI}=0.87$ ] olarak tespit edilmiştir. Bu oranlar detaylı incelendiğinde tüm değerlerin kabul edilebilir uyum değerleri sınırları içinde olduğu anlaşılmaktadır (Özdamar, 2016; Karagöz, 2016; Seçer, 2015, Tabachnick \& Fidel, 2013).

Sonuç olarak iki farklı örnekleme yapılan uygulamalar neticesinde yapılan geçerlilik ve güvenilirlik çalışmalarına göre Enneagram Kişilik Envanteri'nin geçerli ve güvenilir bir envanter olduğu görülmüştür. Envanterden alınan puanların yüksekliği kişide ilgili faktörün ölçtüğü kişilik tipinin güçlü olduğunu göstermektedir. Ancak uzmanlık gerektiren tüm ölçeklerde olduğu gibi Enneagram Türkiye Kişilik Envanteri’nin (ETKE), Enneagram kişilik teorisi konusunda eğitim 
almış, ölçeği uygulamayı bilen kişiler tarafından uygulanması ve uzmanlarca envanter sonuçlarının envanteri kendisine uygulayan kişiyle birlikte değerlendirilmesi önerilmektedir.

\section{Kaynakça}

Ayre, C., \& Scally A. J. (2014). Critical values for Lawshe's content validity ratio: revisiting the original methods of calculation. Measurement and Evaluation in Counseling and Development, 47 (1), 79-86. do1: 10.1177/0748175613513808.

Bennett, J. G. (1974). The enneagram studies, London: Coombe Springs Press.

Bilge, Y. \& Sertel Berk, H. Ö. (2017). Coolidge Eksen II Envanteri Plus'ta (CATI+) yer alan DSMIII-R, DSM-IV-TR VE DSM-5 kişilik bozuklukları alt ölçeklerinin türkçe güvenirlik ve geçerlik çalışması. Uluslararası Sosyal Araştırmalar Dergisi, 10(53),459-474, http://dx.doi.org/10.17719/jisr.20175334134

Bilge, Y. (2018). A brief inventory for DSM-5 personality disorders: The development of Coolidge Axis II Inventory Plus Turkish-Short Form. Anatolian Journal of Psychiatry, 19, 14-21. doi:10.5455/apd.302642951

Büyüköztürk, Ş.(2002). Sosyal bilimler için veri analizi el kitabı. 2. Bask1, Pegem Yayınc1lı, Ankara

Chestnut, Beatrice (2017). The 9 types of leadership: mastering the art of people in the 21 st century workplace. Post Hill Press; Reprint edition (October 24, 2017)

Chestnut, B. (2008). Understanding the development of personality type: 1ntegrating object relations theory and the enneagram system. The Enneagram Journal, 1:22-51

Christlieb, F. F. (2016). Where did the enneagram come from (D. Napolitano, Trans.). Mexico: Fatima Editores.

Coolidge FL. (2006). The coolidge axis $n$ inventory plus-revised: manual. Colorado Springs, CO: Author

Dainels, D. N. ve Price, V. A. (2016). Enneagram kendini bilme sanatı. (3. bs.). (S. D. Çiftçi, Çev.). İstanbul: Kaknüs.

Giordano, M. A. E. (2008). A psychometric evaluation of the Riso- hudson type indicator (RHETI), version 2.5: comparison of ipsative and non-ipsative versions and correlations with spiritual outcomes. (PhD Dissertation). ProQuest Dissertations Publishing. $3365385 . \quad$ Loyola College In Maryland.

Hebenstreit, R. Karl (2016). The how and why: taking care of business with the enneagram: a practical organization development framework to drive more effective, efficient, and sustainable business results and relationships. 1st Edition, CreateSpace Independent Publishing Platform; 1 edition (April 19, 2016), ISBN-13: 978-1519604071

Karagöz Y. (2016). SPSS 23 ve AMOS 23 uygulamalı istatistiksel analizler. Nobel Akademik Yayınc1lı. ISBN: 978-605-320-547-0

Lapid-Bodga, Ginger (2004). Bringing out the best in yourself at work: how to use the enneagram system for success. Paperback - July 1, 2004, McGraw-Hill; 1 edition, ISBN-13: 9780071439602

Lapid-Bodga, Ginger (2009). Bringing out the best in everyone you coach: use the enneagram system for exceptional results. McGraw-Hill Education; 1 edition, ISBN-13: 978-0071637077. 
Lawshe, C. H. (1975). A quantitative approach to content validity. Personnel psychology, 28(4), 563575.

Naranjo, C. (1994). Character and eurosis: an integrative view. Nevada City, CA: Gateways/IDHHB Inc.

Ouespensky, P. D. (2010). Insanın gerçeği “kendini bilmek”. (A. Belbez, E. Konyalığlu, Çev.). (4.bs.). İstanbul: Ruh ve Madde.

Özdamar K. (2016). Eğitim, sağlık ve davranış bilimlerinde ölçek ve test geliştirme yapısal eşitlik modellemesi. Nisan Kitabevi. ISBNÇ:978-975-6428-92-4

Özdoğan, Ö. (2008). İnsana manevi-psikolojik yaklaşım. Ankara Üniversitesi İlahiyat Fakültesi Dergisi, 49(2): 077-102.

Palmer, H. (2014). Ruhun aynası enneagrama yanslyan insan manzaralart. (3. bs.). (O. Gündüz, Çev.). İstanbul: Kaknüs.

Palmer, Helen (1995). The enneagram in love and work: understanding your intimate and business relationships, Harper San Francisco. ISBN 13: 9780062506795

Perry, N. Whitall ve Rafael Lefort (2011). Gürciyev ve gizli üstatlarl sufizmi kullanan modern akımlar. (Çev. Cengiz Erengil). İnsan Yayınları.

Riso, D. R. ve Hudson, R. (2009). Enneagram ile kişilik analizi. (G. Aksoy, Çev.). İstanbul: Butik.

Tabachnick, B. G., \& Fidell, L. S. (2013). Using multivariate statistics. 6. Bask1. USA, Boston, MA: Pearson/ Allyn.

Wagner, J. P. and Walker, R. E. (1983). Reliability and validity Study of a Sufi Personality Typology: The Enneagram. Journal of Clinical Psychology, 39 (5): 712-717. https://doi.org/10.1002/1097- 4679(198309)39:5<712:AID-JCLP2270390511>3.0.CO;23.

Wagner, Jerome P. and Walker, Ronald E. (1983). Reliability and validity study of a sufi personality typology: the enneagram, Journal of Clinical Psychology, September, 1983. Vol. 39, Issue 5: $712-717$.

Y1lmaz, Enver Demirel; Ömer, Aydemir; Sermin, Kesebir; Alp, Örek; Ali, Görkem, Öncer; Ayşe, Yılmaz; Özge, Ünal; Mustafa Bilici (2014). Validity and reliability of nine types temperament scale, dokuz tip mizaç ölçeği'nin geçerlik ve güvenirliği. Eğitim ve Bilim, 39(171):115-137. 


\section{Ek: Etik Kurul Kararı}

Evrak Tarih ve Sayısı: 29/03/2019-E.1743

\section{7) istanbul Zailm Universitesi \\ ETIK KURULU BAŞKANLIĞI}

Sayı : 20292139-050.01.04

Konu : Etik Kurul Kararları

\section{Saym Dr. Öğr. Üyesi Turgay şiRíN}

Kurulumuz 21.03.2019 tarihinde toplanarak, "Enneagram Kişilik Ölçeği Geçerlik ve Güvenirlik Çalışması" başlıklı araştırmanızda kullanmak üzere kurula sunmuş olduğunuz Etik Kurul Başvuru Formunuzu onaylayarak imza altına almışıిı. Araştırmanızın Etik Kurul Onay Formu ekte yer almaktadır. Bilgilerinizi rica ederim.

e-imzalıdır

Prof. Dr. Nasuh USLU

Kurul Başkanı

Ek:Etik Kurul Başvuru Formu (3 sayfa) 
21.03.2019 tarihli ve 2019/03 sayılı Etik Kurul Kararı ekidir.

\begin{tabular}{|c|c|c|}
\hline 7) & & $\begin{array}{l}\text { İSTANBUL SABAHATTIN ZAIM ÜNIVERSITTESİ } \\
\text { ETIK KURULU }\end{array}$ \\
\hline \multicolumn{3}{|r|}{ ARASTTIRMA ETIKK KURUL ONAY FORMU } \\
\hline Tarih: & \multicolumn{2}{|r|}{21.03 .2019} \\
\hline Sayı: & \multicolumn{2}{|r|}{$2019 / 03$} \\
\hline Ekler: & \multicolumn{2}{|c|}{$\begin{array}{l}\text { EK 1: Başvuru Dilekçesi } \\
\text { EK 2: Etik Davranıș Beyan Formu } \\
\text { EK 3: Etik Kurul Bașvuru Formu } \\
\text { EK 4: Bilgilendirilmiș Gönüllü Onam Formu } \\
\text { EK:5: Kișisel Bilgi Formu } \\
\text { EK 6: Anketler (5sayfa) }\end{array}$} \\
\hline Yer: & \multicolumn{2}{|r|}{ İstanbul Sabahattin Zaim Üniversitesi Rektörlüğü } \\
\hline İlgi: & \multicolumn{2}{|r|}{ Eğitim Fakültesi Dekanlığının 15.03.2019 tarihli ve 1434 sayılı yazısı } \\
\hline Katılımeılar: & & $\begin{array}{ll}\text { Prof. Dr. Nasuh USLU } & \text { Kurul Bașkanı/Rektör Yardımcısı } \\
\text { Prof. Dr. Mehmet Emin KÖKTAȘye/Dekan V. } & \text { Üye/Dekan V. } \\
\text { Prof. Dr. Mehmet KUTLU } & \text { Üye/Dekan V. } \\
\text { Prof. Dr. Mustafa ATEȘ } & \text { Üye/Dekä. } \\
\text { Prof. Dr. Ömer ÇAHA } & \text { Üye/Müdür V. } \\
\text { Prof. Dr. Yahya Kemal YOĞURTÇU } & \text { Üye/Ögretim Üyesi } \\
\text { Bilal ȘAMAT } & \text { Üye/Hukuk Müșaviri } \\
\end{array}$ \\
\hline \multicolumn{3}{|c|}{ Planlanan araștırma önerisi özeti așağıdaki gibidir. } \\
\hline \multicolumn{2}{|c|}{ Araștırmanın Niteliği: } & Tanımlayıcı (İlișkisel) tipte bir çalıșmadır. \\
\hline \multicolumn{2}{|l|}{ Araștırmanın Bașlığı: } & Enneagram Kișilik Ölçeği Geçerlik ve Güvenirlik Çalıșması \\
\hline \multicolumn{2}{|c|}{$\begin{array}{l}\text { Arașturmacılar ve adres } \\
\text { bilgisi: }\end{array}$} & 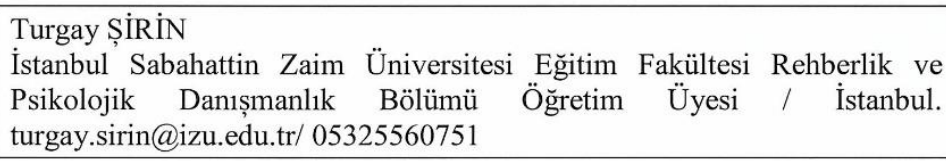 \\
\hline \multicolumn{2}{|c|}{ Araștırmanın Süresi (ay): } & 3 ay. \\
\hline Araștırmanın Amacı: & & $\begin{array}{l}\text { Bu araștırma, Enneagram Kișilik Ölçeği’nin Türkiye versiyonunun } \\
\text { geliștirilmesi ve psikometrik özelliklerinin belirlenmesi amacıyla } \\
\text { yapılmaktadır. } \\
\text { Günümüzde gittikçe daha çok uzman tarafindan ilgi gören Enneagram } \\
\text { kișilik teorisi, kendisini İslam tasavvuf öğretisiyle ilișkilendiren bir sistem } \\
\text { olarak da bilinmektedir. Binlerce yıllık kadim sufi bilgeliği olarak } \\
\text { isimlendirilen ve insanın kendi gerçek doğasını anlaması için günümüzün } \\
\text { popüler kișilik tipi sistemi olarak anılan Enneagram, dünyada Stanford ve } \\
\text { Harvard gibi pek çok üniversitenin psikoloji, hukuk, ișletme ve eğitim } \\
\text { bölümlerinde ders olarak da okutulmaktadır. }\end{array}$ \\
\hline
\end{tabular}


21.03.2019 tarihli ve 2019/03 say1lı Etik Kurul Kararı ekidir.

\begin{tabular}{|c|c|}
\hline Arașturma Etiği: & $\begin{array}{l}\text { Araștırmaya kurum izni ve gönüllü katılım için sözlü ve yazılı onam } \\
\text { alındıktan sonra bașlanacaktır. } \\
\text { Çalıșmanın bilimsel bir araștırma için veri toplamayı amaçladığı, çalıșma } \\
\text { sonuçlarının sadece bilimsel amaçlarla kullanılacağı, çalıșmanın } \\
\text { sonuçlarının katılımcıların aleyhine olacak șekilde kullanılmayacağı, } \\
\text { çalıșmaya katılımın gönüllülük esasına dayandığı, cevapların tamamen gizli } \\
\text { tutulacağı, çalıșmaya katılanların kimliklerini açık edici davranıșlardan } \\
\text { kaçınılacağı ve çalıșmaya katılanların katılım sırasında herhangi bir nedenle } \\
\text { rahatsızlık hissetmeleri durumunda istedikleri zaman katılımlarını sona } \\
\text { erdirebilecekleri bilgileri uygulanacak anketlerin bașında yer almaktadır. }\end{array}$ \\
\hline $\begin{array}{l}\text { Araștırmada } \\
\text { Kullanılacak Ölçme } \\
\text { Araçları (adları): }\end{array}$ & $\begin{array}{l}\text { Araștırmada veri toplamak için, araștırmacı tarafindan ilgili literatür } \\
\text { incelenerek geliștirilen ölçek sorularından olușan Enneagram Kișilik Ölçeği } \\
\text { ve demografik bilgiler için geliștirilen kișisel bilgi formu kullanılacaktır. }\end{array}$ \\
\hline $\begin{array}{l}\text { Araștırmaya Katılacak } \\
\text { Örneklem Sayısı, } \\
\text { Örneklemin Nereden ve } \\
\text { Nasıl Seçileceği: }\end{array}$ & $\begin{array}{l}\text { Araștırma örneklemini İstanbul Sabahattin Zaim Üniversitesi öğrencileri ile } \\
\text { gerek üniversite dıșından gerek Google anket formu üzerinden gerekse } \\
\text { yüzyüze görüșmeler neticesinde araștırmaya gönüllü olarak katılacak } \\
\text { bireyler olușturacaktır. } \\
\text { Örneklem sayısı literatürde önerildiği șekliyle, ölçek madde sayısının } \\
\text { minimum } 5 \text { katı olmasına dikkat edilerek yaklașık 300'ü erkek 300’ü kadın } \\
\text { olmak üzere toplam } 600 \text { kișilik toplum ve öğrenci katılımcıdan olușacaktır. } \\
\text { Veriler ulașılabilirlik ve elverișlilik ilkesine göre toplanacaktır. } \\
\text { Katılımcılara bilgilendirilmiș onam formu imzalatılacak ve araștırmayla } \\
\text { ilgili bilgi verilecektir. }\end{array}$ \\
\hline $\begin{array}{l}\text { Uygulamanın veya } \\
\text { Ölçeklerin Doldurma } \\
\text { Süresi }\end{array}$ & $\begin{array}{l}\text { Enneagram kișilik ölçeği ve kișisel bilgi formundan olușan veri toplama } \\
\text { araçlarının ölçek doldurma süresi yaklașı 20-30 dakika sürmektedir. }\end{array}$ \\
\hline KARAR & $\begin{array}{l}\text { ARAŞTIRMA İSTANBUL SABAHATTIN ZAIMM } \\
\text { ÜNIVERSITESINIIN ETIK DURUȘUNA AYKIRI DEĞILDİR. }\end{array}$ \\
\hline
\end{tabular}

Tarih: 21/03/2019

Sayı: $2019 / 03$

İlgi: Eğitim Fakültesi Dekanlığının 15.03.2019 tarihli ve 1434 sayılı yazısı

İstanbul Sabahattin Zaim Üniversitesi Etik Kurulu tarafından hazırlanmıștır. 
21.03.2019 tarihli ve 2019/03 sayılı Etik Kurul Kararı ekidir.

Bașkan

Prof. Dr. Nasuh USLU

Prof. Dr. Mehmet Emin KÖKYA

Prof. Dr. Mustafa ATES

Prof. Dr. Yahya Kełnal YOĞUTÇU
Üye

Prof. Dr. Mehmet KUTLU

Üye'

Prof. Dr. ÖmerषAHA

1 vüye

Av. Bilal SAMAT 